\title{
Article \\ Effects of Different Inter-Row Soil Management and Intra-Row Living Mulch on Spontaneous Flora, Beneficial Insects, and Growth of Young Olive Trees in Southern Italy
}

\author{
Giuseppina Las Casas ${ }^{1,+}$, Corrado Ciaccia ${ }^{2,+}{ }^{(\mathbb{C}}$, Valeria Iovino ${ }^{1}$, Filippo Ferlito ${ }^{1, *} \mathbb{C}$, Biagio Torrisi ${ }^{1}$, \\ Enrico Maria Lodolini ${ }^{3, *(\mathbb{D}}$, Alessio Giuffrida ${ }^{1}{ }^{(\mathbb{C}}$, Roberto Catania ${ }^{1}{ }^{\mathbb{D}}$, Elisabetta Nicolosi ${ }^{4}{ }^{\mathbb{D}}$ and Salvatore Bella ${ }^{1}$ \\ 1 Consiglio per la Ricerca in Agricoltura e l'Analisi dell'Economia Agraria (CREA) - Centro di Ricerca \\ Olivicoltura, Frutticoltura e Agrumicoltura, Corso Savoia 190, 95024 Acireale, Italy; \\ giuseppina.lascasas@crea.gov.it (G.L.C.); iovino.valeri@gmail.com (V.I.); \\ biagiofrancesco.torrisi@crea.gov.it (B.T.); alessio020594@live.it (A.G.); robertocatania1995@libero.it (R.C.); \\ salvatore.bella@crea.gov.it (S.B.) \\ 2 Consiglio per la Ricerca in Agricoltura e l'Analisi dell'Economia Agraria (CREA) - Centro di Ricerca \\ Agricoltura e Ambiente, Via della Navicella 4, 00184 Roma, Italy; corrado.ciaccia@crea.gov.it \\ 3 Consiglio per la Ricerca in Agricoltura e l'Analisi dell'Economia Agraria (CREA) - Centro di Ricerca \\ Olivicoltura, Frutticoltura e Agrumicoltura, Via Fioranello 52, 00134 Roma, Italy \\ 4 Dipartimento di Agricoltura, Alimentazione e Ambiente (Di3A), Università di Catania, Via Valdisavoia 5, \\ 95123 Catania, Italy; elisabetta.nicolosi@unict.it \\ * Correspondence: filippo.ferlito@crea.gov.it (F.F.); enricomaria.lodolini@crea.gov.it (E.M.L.); \\ Tel.: +39-09571-63111 (F.F.) \\ check for \\ updates \\ $+\quad$ These authors contributed equally to this work.
}

Citation: Las Casas, G.; Ciaccia, C.; Iovino, V.; Ferlito, F.; Torrisi, B.; Lodolini, E.M.; Giuffrida, A.; Catania, R.; Nicolosi, E.; Bella, S. Effects of Different Inter-Row Soil Management and Intra-Row Living Mulch on Spontaneous Flora, Beneficial Insects, and Growth of Young Olive Trees in Southern Italy. Plants 2022, 11, 545. https://doi.org/10.3390/ plants11040545

Academic Editors: Alessia Restuccia, Aurelio Scavo and Adriano Sofo

Received: 16 December 2021 Accepted: 15 February 2022 Published: 18 February 2022

Publisher's Note: MDPI stays neutral with regard to jurisdictional claims in published maps and institutional affiliations.

Copyright: (c) 2022 by the authors. Licensee MDPI, Basel, Switzerland. This article is an open access article distributed under the terms and conditions of the Creative Commons Attribution (CC BY) license (https:// creativecommons.org/licenses/by/ $4.0 /)$.

\begin{abstract}
Conservation agriculture (i.e., minimized soil disturbance and permanent soil covering) and living mulches represent two agroecological practices that can improve soil fertility, spontaneous flora, and beneficial insect communities. This research studied the effect of these practices in a young olive orchard in the Mediterranean area. Two Sicilian olive cultivars ('Nocellara del Belice' and 'Nocellara etnea') were used for the field experiment; inter-row minimum and zero tillage and four species of aromatic plants as living mulch along the row were tested. Spontaneous flora and beneficial insect communities, as well as tree growth, were monitored. The inter-row management did not influence the spontaneous flora dynamics. The species adopted for living mulch showed a very different degree of development and soil cover; 69 insect species (pollinators and predators) belonging to five orders (Hymenoptera, Lepidoptera, Diptera, Neuroptera, and Coleoptera) and 17 families were recorded. The growth of the olive trees was not affected by the conservative strategies.: In the inter-row, the growth of the spontaneous flora was limited by the high temperatures during the summer. Among the living mulch species, sage and lemongrass guaranteed an almost full soil cover, reducing the need for weed management along the row, as well as increasing the beneficial insects without influencing the young tree growth.
\end{abstract}

Keywords: Olea europaea L.; Mediterranean basin; agroecological practices; minimum tillage; zero tillage; pollinating and predatory insects; agroforestry; intercropping; consociation

\section{Introduction}

One of the main goals established by the European Commission during the period 2019-2024 is to lay the foundation for making the European Union the first climate-neutral continent by 2050. To achieve this objective, the Commission presented the European Green Deal policy, the most ambitious package of measures that should enable European citizens and businesses to benefit from sustainable green transition. Concerning the agricultural sector, this objective will be reached by a drastic reduction in farm input (fertilizers, chemical pesticide, hormones), reducing the nutrient losses and preserving and restoring ecosystems and biodiversity [1]. 
Currently, this policy is mandatory considering the ongoing climate change and its impact on agriculture (increase in average temperature and risk of extreme natural events such as floods and droughts) and the land degradation process (erosion, salinity, soil borne diseases) occurring in large areas of the world and the subsequent loss of biodiversity. Moreover, it is important to consider that the world population will increase in the same period (2050) and will reach about 9.1 billion people [2], consequently increasing the food demand [3]. Therefore, in this scenario, agricultural sectors also need to increase the crop efficiency, since the land availability and productivity will play a central role for the maintenance of several rural contexts [4].

The Mediterranean basin is a representative area in which the abovementioned criticisms are well recognized. Among fruit tree crops, the olive (Olea europaea L.), one of the most cultivated species that covers about 9.5 million hectares in Europe [5], is an important crop for its social, economic, and ecological role [6].

Regarding the social aspect, it is able to contrast the depopulation of the countryside, as well as maintain the historical aspect of its cultivation [7], providing healthy and safe food for the population. In addition, olive cultivation connects different generations because most of the farmers cultivating traditional olive orchards are aged or retired people, who are still active in agriculture and share their knowledge with younger people in order to maximize the production only using the potential of the agroecosystem [8].

The economic role is well documented; in fact, the olive production has increased in recent years due to the introduction of new planting models [9], mechanization of some cultural practices, harvest above all [10], precision management technologies [11,12], and the use of high-quality standard propagation material [13]. Moreover, at least $95 \%$ of the olive cultivation is located in the Mediterranean basin [14], and it represents about $70 \%$ of world's olive production [15], from about 1.9 million olive-growing farms.

In terms of the agroecological value, olive plays a fundamental role in maintaining some fragile areas, preventing soil erosion, as well as loss of water and nutrients, and increasing biodiversity. Moreover, thanks to its historical aspect and adaptation, compared to the other woody crops, olive cultivation does not require high external inputs, thus contributing to reducing environmental pollution [16]. On the other hand, tillage (full or partial) is often realized, while minimum and zero tillage is less adopted. Low-intensity tillage leads to an increase in the number of beneficial insects such as pollinators [17] that sustain wild plant communities providing key ecosystem services (e.g., contributing to control pest and crop disease) [18]. As demonstrated by different studies, various anthropogenic factors, such as the expansion of agriculture and livestock, habitat fragmentation, and irrational use of pesticides and pollution, are causing a global decline in insects [19]. In Europe, 9\% of butterflies and $9.2 \%$ of wild bees are threatened by conventional agriculture [20]. Conservative agriculture (e.g., minimized soil disturbance, permanent soil covering) has been shown to have an impact on biodiversity and ecosystem service provision [21], reducing the negative effects of conventional tillage and enhancing the number of beneficial insects, as well as improving their role in the agroecosystem. Similarly, diversification strategies in space and time by the inclusion of agroecological infrastructure in agricultural landscape such as hedgerows and cover crops (including living mulch) are considered redesign strategies able to magnify the role of agro-biodiversity in ecosystem service provision [22,23]. Moreover, the management strategies can impact the spontaneous flora community (i.e., the weeds), reducing the selection of competitive flora toward a more service provisionoriented community, by supporting pollinators or beneficial attraction [24]. Then, the introduction of herbaceous species (e.g., intercropping, living mulch) that are not directly aimed at production but provide ecological services, called agroecological service crops (ASC) [25], can positively influence the overall ecosystem functioning by providing pest control and ecological services such as weed control in the row [26], protection of the soil from degradation, an increase in organic carbon content, which improves the soil structure and fertility [27], and a decrease in the concentration of $\mathrm{CO}_{2}$ in the atmosphere if properly managed [28]. Among the conservative soil management strategies, consociations (annual 
or perennial intercropping), soil management practices (minimum tillage, zero tillage), and organic fertilization were considered for a comprehensive meta-analysis (187 experiments realized in the Mediterranean basin with several woody crops for a total of 46 papers) [29] that highlighted a general positive effect of the abovementioned strategies in carbon sequestration compared to mono-cropping, conventional tillage, and inorganic fertilization. For olive, since the last century, consociations with herbaceous or woody species have been described [30]. These were due to the extensive olive orchards, as well as the consociations with livestock where possible [31]. For other species such as grapevines, minimum or zero tillage is commonly applied in order to regulate the vegetative and reproductive balance of vines and, in some cases, in order to reduce erosion and land degradation [32-34].

In this context, olive could represent an important source of ecological interest among the numerous Mediterranean species due to its specific characteristics, such as high drought resistance, low chill unit requirement, adaptation to hot and dry climatic conditions, and low pest and disease incidence, all of which are significant characteristics to consider in the establishment of new orchards with an agro-ecological approach [35]. However, it is important to consider that the cultivation of olive trees is very diversified among the Mediterranean countries, and that the social, economic, and agroecological value of the olive orchards is strongly variable according to the different cultivation systems (traditional, intensive, and super-intensive orchards), farming techniques, and genetic resources [36]. In traditional orchards, the social and agroecological characteristics are highly relevant, whereas, in the intensive model, only the olive agroecological importance is essential. In these categories, olive models are in accordance with the main objectives of the agroecological approach, which aims to reinforce the natural strength of the agroecosystem without using external inputs and augment the resilience of the crops, encompassing the social, ecological, and economic dimensions of sustainability [37]. In the super-intensive growing system, the economic factor is of greater importance than the social and agroecological factors.

In our research, we tested the impact of some agroecological practices (i.e., conservative soil management and ASC living mulch introduction) on the wild agro-biodiversity (weed and arthropod communities) and vegetative growth of a newly planted olive orchard. We assumed that different floor management (minimum tillage vs. zero tillage) and intra-row management (different living mulch species vs. no living mulch) would differently influence the dynamics of the monitored agro-biodiversity and the young plant response. In particular, we hypothesized that (i) the zero-tillage floor management would guarantee permanent soil cover without selecting higher competitive flora, (ii) the living mulches would positively influence the presence of beneficial insects, and (iii) different living mulches would have a different impact on both arthropods and weed communities, depending on the introduced species.

\section{Results}

\subsection{Entomological Report}

The complete list of the 69 recorded species of beneficial insects, as well as their relation to the spontaneous flora or the consociated ones, in the studied olive orchard is reported in Tables 1 and 2. Specimens of pollinators (61 species) and predators (eight species) were collected in the 2 years of field surveys on the wild and cultivated plants. Regarding pollinators, the 33 species of Apoidea reported belong to five different families, Colletidae (one species), Andrenidae (seven species), Halictidae (four species), Megachilidae (five species), and Apidae (16 species), and 15 genera (Table 1). Most of these species nest by digging into the ground ( 24 species, $72.72 \%$ ), while $21.21 \%$ (seven species) of the taxa nest in pre-existing cavities in the ground, in the walls, or in dry and hollow vegetables. Two species among the 33 observed $(6.06 \%)$ belong to the Nomada Scopoli genus of brood parasitic bees characterized by the presence of females that lay eggs in the nest of other wild bees. Regarding the behavior, 24 species are solitary $(72.72 \%)$, five species $(15.15 \%)$ exhibit a pre-social behavior, two species $(6.06 \%)$ have a social behavior, and two species $(6.06 \%)$ are brood parasite species. 
Table 1. Hymenoptera Apoidea, Lepidoptera, Diptera, Neuroptera, and Coleoptera collected in the years 2020-2021 in the field inter-rows, and in the year 2021 in the consociated rows. * In this species, the larvae are predators.

\begin{tabular}{|c|c|c|c|c|}
\hline Order & Family & Species & $\begin{array}{l}\text { Wild Plants in the } \\
\text { Inter-Rows }\end{array}$ & $\begin{array}{l}\text { Consociated Plants } \\
\text { in the Row }\end{array}$ \\
\hline \multirow{29}{*}{ Hymenoptera } & & Pollinators & & \\
\hline & Colletidae & Hylaeus cornutus Curtis, 1831 & Foeniculum vulgare & Helichrysum italicum \\
\hline & \multirow{7}{*}{ Andrenidae } & Andrena aerinifrons Dours, 1873 & $\begin{array}{c}\text { Sinapis arvensis } \\
\text { Ranunculus muricatus }\end{array}$ & \\
\hline & & Andrena bicolorata (Rossi, 1790) & Sinapis arvensis & \\
\hline & & $\begin{array}{l}\text { Andrena pilipes } \\
\text { Fabricius, } 1781\end{array}$ & Senecio vulgaris & \\
\hline & & Andrena brumanensis Friese, 1899 & Ranunculus muricatus & Salvia officinalis \\
\hline & & $\begin{array}{l}\text { Andrena distinguenda } \\
\text { Schenck, } 1871\end{array}$ & Glebionis coronaria & \\
\hline & & Andrena labialis (Kirby, 1802) & Ecballium elaterium & \\
\hline & & $\begin{array}{l}\text { Andrena nigroaenea } \\
\text { (Kirby, 1802) }\end{array}$ & Sinapis arvensis & \\
\hline & \multirow{4}{*}{ Halictidae } & Halictus fulvipes (Klug, 1817) & Galactites tomentosa & Thymus vulgaris \\
\hline & & $\begin{array}{l}\text { Halictus quadricinctus (Fabricius, } \\
\text { 1776) }\end{array}$ & Senecio vulgaris & \\
\hline & & Halictus scabiosae (Rossi, 1790) & $\begin{array}{l}\text { Senecio vulgaris } \\
\text { Dittrichia viscosa }\end{array}$ & Thymus vulgaris \\
\hline & & $\begin{array}{l}\text { Lasioglossum malachurum } \\
\text { (Kirby, 1802) }\end{array}$ & Ecballium elaterium & Helichrysum italicum \\
\hline & \multirow{5}{*}{ Megachilidae } & Heriades rubicola Pérez, 1890 & Dittrichia viscosa & Helichrysum italicum \\
\hline & & $\begin{array}{l}\text { Osmia latreillei } \\
\text { (Spinola, 1806) }\end{array}$ & Glebionis coronaria & Salvia officinalis \\
\hline & & Osmia signata Erichson, 1835 & Glebionis coronaria & \\
\hline & & $\begin{array}{l}\text { Rhodanthidium siculum } \\
\text { (Spinola, 1838) }\end{array}$ & Oxalis pes-caprae & Salvia officinalis \\
\hline & & Megachile sicula (Rossi, 1792) & Galactites tomentosa & \\
\hline & \multirow{11}{*}{ Apidae } & Xylocopa violacea (Linnaeus, 1758 ) & - & $\begin{array}{l}\text { Salvia officinalis } \\
\text { Thymus vulgaris }\end{array}$ \\
\hline & & Ceratina cyanea Kirby, 1802 & Ecballium elaterium & Helichrysum italicum \\
\hline & & $\begin{array}{l}\text { Nomada discrepans } \\
\text { Schmiedeknecht, } 1882\end{array}$ & Sinapis arvensis & \\
\hline & & $\begin{array}{l}\text { Nomada distinguenda } \\
\text { Morawitz, } 1874\end{array}$ & Raphanus raphanistrum & \\
\hline & & Eucera algira Brullé, 1840 & Raphanus raphanistrum & \\
\hline & & Eucera eucnemidea Dours, 1873 & Galactites tomentosa & \\
\hline & & Eucera nigrescens Pérez, 1879 & $\begin{array}{l}\text { Glebionis coronaria; } \\
\text { Vicia sp. }\end{array}$ & \\
\hline & & Eucera nigrilabris Lepeletier, 1841 & Raphanus raphanistrum & \\
\hline & & Eucera numida Lepeletier, 1841 & Vicia sativa & \\
\hline & & Eucera oraniensis Lepeletier, 1841 & $\begin{array}{l}\text { Glebionis coronaria } \\
\text { Galactites tomentosa }\end{array}$ & Salvia officinalis \\
\hline & & Amegilla garrula (Rossi, 1790) & - & $\begin{array}{l}\text { Salvia officinalis } \\
\text { Thymus vulgaris }\end{array}$ \\
\hline
\end{tabular}


Table 1. Cont.

\begin{tabular}{|c|c|c|c|c|}
\hline Order & Family & Species & $\begin{array}{l}\text { Wild Plants in the } \\
\text { Inter-Rows }\end{array}$ & $\begin{array}{c}\text { Consociated Plants } \\
\text { in the Row }\end{array}$ \\
\hline & & $\begin{array}{l}\text { Amegilla quadrifasciata } \\
\text { (de Villers, 1789) }\end{array}$ & - & $\begin{array}{l}\text { Salvia officinalis } \\
\text { Thymus vulgaris }\end{array}$ \\
\hline & & Anthophora dispar Lepeletier, 1841 & Fumaria officinalis & Salvia officinalis \\
\hline & & $\begin{array}{l}\text { Anthophora plumipes squalens } \\
\text { Dours, } 1869\end{array}$ & $\begin{array}{l}\text { Fumaria officinalis } \\
\text { Papaver rhoeas }\end{array}$ & \\
\hline & & $\begin{array}{l}\text { Bombus pascuorum siciliensis } \\
\text { Tkalcu, } 1977\end{array}$ & Vicia sativa & $\begin{array}{l}\text { Salvia officinalis } \\
\text { Thymus vulgaris }\end{array}$ \\
\hline & & Bombus terrestris (Linnaeus, 1758) & Vicia sativa & $\begin{array}{c}\text { Salvia } \\
\text { officinalisThymus } \\
\text { vulgaris }\end{array}$ \\
\hline \multirow{21}{*}{ Lepidoptera } & \multirow{3}{*}{ Sphingidae } & $\begin{array}{l}\text { Macroglossum stellatarum } \\
\text { (Linnaeus, 1758) }\end{array}$ & Convolvulus arvensis & Thymus vulgaris \\
\hline & & Hyles euphorbiae (Linnaeus, 1758 ) & - & \\
\hline & & Hyles livornica (Esper, 1780) & Convolvulus arvensis & Helichrysum italicum \\
\hline & Sesiidae & Tinthia tineiformis (Esper, 1789) & Convolvulus arvensis & \\
\hline & \multirow{2}{*}{ Geometridae } & $\begin{array}{l}\text { Rhodometra sacraria } \\
\text { (Linnaeus, 1767) }\end{array}$ & - & Thymus vulgaris \\
\hline & & $\begin{array}{l}\text { Menophra abruptaria } \\
\text { (Thunberg, 1792) }\end{array}$ & Dittrichia viscosa & Thymus vulgaris \\
\hline & \multirow[b]{2}{*}{ Noctuidae } & $\begin{array}{l}\text { Heliothis peltigera } \\
\text { (Denis \& Schiffermüller, 1775) }\end{array}$ & Senecio vulgaris & $\begin{array}{l}\text { Helichrysum italicum } \\
\text { Thymus vulgaris }\end{array}$ \\
\hline & & $\begin{array}{l}\text { Autographa gamma } \\
\text { (Linnaeus, 1758) }\end{array}$ & & Salvia officinalis \\
\hline & Hesperiidae & Carcharodus alceae (Esper, 1780) & Lysimachia arvensis & Thymus vulgaris \\
\hline & \multirow[b]{2}{*}{ Lycaenidae } & $\begin{array}{l}\text { Lycaena alciphron } \\
\text { (Rottemburg, 1775) }\end{array}$ & Althaea officinalis & Thymus vulgaris \\
\hline & & Lycaena phlaeas (Linnaeus, 1761) & $\begin{array}{c}\text { Polygonum aviculare } \\
\text { Portulaca oleracea } \\
\text { Ranunculus muricatus }\end{array}$ & Thymus vulgaris \\
\hline & \multirow{5}{*}{ Nymphalidae } & Aglais urticae (Linnaeus, 1758) & Althaea officinalis & Helichrysum italicum \\
\hline & & Vanessa atalanta (Linnaeus, 1758) & $\begin{array}{c}\text { Althaea officinalis } \\
\text { Convolvulus arvensis } \\
\text { Ecballium elaterium }\end{array}$ & $\begin{array}{l}\text { Salvia officinalis } \\
\text { Thymus vulgaris }\end{array}$ \\
\hline & & Vanessa cardui (Linnaeus, 1758) & Ranunculus muricatus & Thymus vulgaris \\
\hline & & $\begin{array}{l}\text { Lasiommata megera } \\
\text { (Linnaeus, 1767) }\end{array}$ & Polygonum aviculare & $\begin{array}{l}\text { Salvia officinalis } \\
\text { Thymus vulgaris }\end{array}$ \\
\hline & & Pararge aegeria (Linnaeus, 1758) & - & Thymus vulgaris \\
\hline & \multirow[t]{2}{*}{ Papilionidae } & $\begin{array}{l}\text { Iphiclides podalirius } \\
\text { (Linnaeus, 1758) }\end{array}$ & - & Helichrysum italicum \\
\hline & & Papilio machaon Linnaeus, 1758 & Dittrichia viscosa & \\
\hline & \multirow{3}{*}{ Pieridae } & Colias croceus (Geoffroy, 1785) & Ecballium elaterium & Thymus vulgaris \\
\hline & & $\begin{array}{l}\text { Gonepteryx cleopatra } \\
\text { (Linnaeus, 1767) }\end{array}$ & - & Thymus vulgaris \\
\hline & & & $\begin{array}{l}\text { Capsella bursa-pastoris } \\
\text { Raphanus raphanistrum } \\
\text { Sinapis arvensis }\end{array}$ & \\
\hline
\end{tabular}


Table 1. Cont.

\begin{tabular}{|c|c|c|c|c|}
\hline Order & Family & Species & $\begin{array}{l}\text { Wild Plants in the } \\
\text { Inter-Rows }\end{array}$ & $\begin{array}{c}\text { Consociated Plants } \\
\text { in the Row }\end{array}$ \\
\hline & & Pieris mannii (Mayer, 1851) & Beta vulgaris & \\
\hline & & Pieris rapae (Linnaeus, 1758) & $\begin{array}{l}\text { Portulaca oleracea } \\
\text { Sinapis arvensis }\end{array}$ & Thymus vulgaris \\
\hline \multirow{5}{*}{ Diptera } & \multirow{5}{*}{ Syrphidae } & $\begin{array}{l}\text { Episyrphus balteatus } \\
\text { (DeGeer, 1776) * }\end{array}$ & - & Thymus vulgaris \\
\hline & & Eupeodes luniger (Meigen, 1822) * & Ranunculus muricatus & \\
\hline & & $\begin{array}{l}\text { Eristalinus taeniops } \\
\text { (Wiedemann, 1818) }\end{array}$ & $\begin{array}{c}\text { Beta vulgaris } \\
\text { Polygonum aviculare }\end{array}$ & Thymus vulgaris \\
\hline & & Eristalis tenax (Linnaeus, 1758) & - & $\begin{array}{l}\text { Helichrysum italicum } \\
\text { Thymus vulgaris }\end{array}$ \\
\hline & & Syritta pipiens (Linnaeus, 1758) & Portulaca oleracea & \\
\hline \multicolumn{5}{|l|}{ Predators } \\
\hline \multirow[b]{2}{*}{ Neuroptera } & \multirow[b]{2}{*}{ Chrysopidae } & Chrysopa viridana Schneider, 1845 & - & Thymus vulgaris \\
\hline & & $\begin{array}{l}\text { Chrysoperla carnea } \\
\text { (Stephens, 1836) }\end{array}$ & $\begin{array}{c}\text { Ranunculus muricatus } \\
\text { Beta vulgaris }\end{array}$ & $\begin{array}{c}\text { Salvia officinalis } \\
\text { Helichrysum italicum }\end{array}$ \\
\hline \multirow{6}{*}{ Coleoptera } & \multirow{6}{*}{ Coccinellidae } & $\begin{array}{l}\text { Chilocorus bipustulatus } \\
\text { (Linnaeus, 1758) }\end{array}$ & Ecballium elaterium & Thymus vulgaris \\
\hline & & $\begin{array}{l}\text { Coccinella septempunctata } \\
\text { Linnaeus, } 1758\end{array}$ & $\begin{array}{l}\text { Amaranthus retroflexus } \\
\text { Diplotaxis erucoides }\end{array}$ & $\begin{array}{l}\text { Helichrysum italicum } \\
\text { Salvia officinalis }\end{array}$ \\
\hline & & $\begin{array}{l}\text { Hippodamia variegata } \\
\text { (Goeze, 1777) }\end{array}$ & Cerinthe major & - \\
\hline & & $\begin{array}{l}\text { Propylea quatuordecimpunctata } \\
\text { (Linnaeus, 1758) }\end{array}$ & Althaea officinalis & - \\
\hline & & $\begin{array}{l}\text { Scymnus interruptus } \\
\text { (Goeze, 1777) }\end{array}$ & Salvia officinalis & Senecio vulgaris \\
\hline & & $\begin{array}{l}\text { Scymnus subvillosus } \\
\text { (Goeze, 1777) }\end{array}$ & Diplotaxis erucoides & \\
\hline
\end{tabular}


Table 2. Seasonal presence of Apoidea species in the experimental farm of Palazzelli during the years 2020-2021.

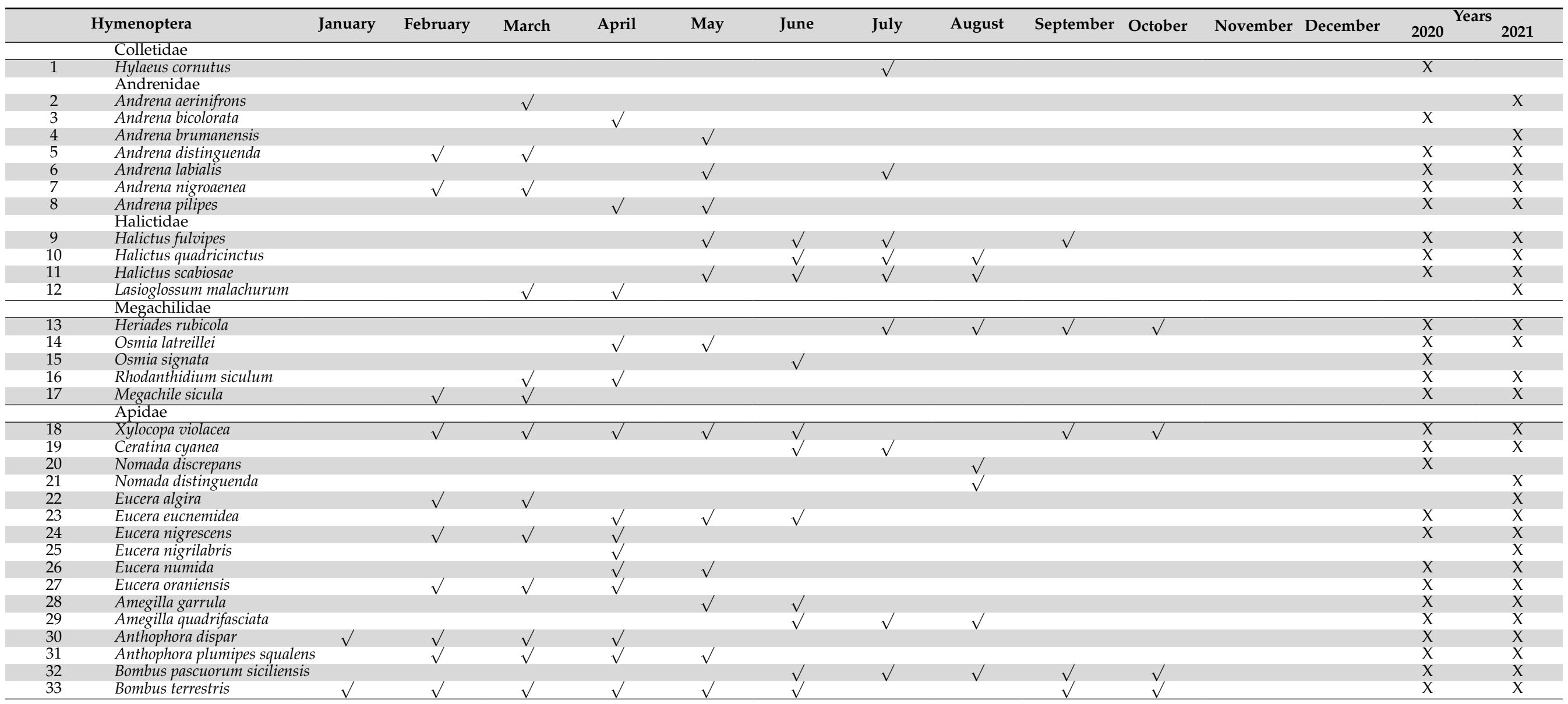


The 23 species of Lepidoptera reported belong to nine different families, Sphingidae (three species), Sesiidae (one species), Geometridae (two species), Noctuidae (two species) Hesperiidae (one species), Lycaenidae (two species), Nymphalidae (five species), Papilionidae (two species), and Pieridae (five species), and 17 genera (Table 1).

Five species (and five genera) of Diptera were found belonging to the Syrphidae family. The adults of these species are pollinators of spontaneous plants; however, the larvae have different trophic regimes. For example, larvae of Episyrphus balteatus (DeGeer), and Eupeodes luniger (Meigen) are predators of aphids, while those of Eristalinus taeniops (Wiedemann), Eristalis tenax (L.), and Syritta pipiens (L.) are scavengers [38].

Furthermore, regarding predator insects, two species of Neuroptera Chrysopidae and six species of Coleoptera Coccinellidae were found; among these, one species feeds mainly on coccids, while the others feed mainly on aphids.

\subsection{Spontaneous Flora Distribution and Diversity}

The complete list of the spontaneous flora species found in the field, as well as the time (spring or autumn) and the area in which they were recorded (inter-row or intrarow), is reported in Table 3. A total of 40 species of plants are listed. Among these, five species, Amaranthus retroflexus L. (AMARE), Cynodon dactylon (L.) Pers. (CYNDA), Cyperus rotundus L. (CYPRO), Polygonum aviculare L. (POLAV), and Portulaca oleracea L. (POROL), were found in each period and position. In spring, 28 species of plants were detected: 14 of them both in the intra-row and inter-row, and the remaining 14 exclusively in the intra-row. On the contrary, no exclusive species in the inter-row were observed. In autumn, 26 species were observed, and only eight grew both in inter-row and intra-row. In this period, six species were exclusive in the inter-row while 11 species were found only along the row.

Regarding the weed monitoring achieved in spring in the inter-row, in MT treatments, most of the space $(70 \%)$ was classified as bare soil, while the predominant spontaneous plants were Portulaca oleracea (POROL) (11\%) and Convolvulus arvensis L. (CONAR) $(7 \%)$, even though the quantity was lower compared to the ZT treatment. In these areas, the bare soil was in less quantity $(18 \%)$, and the predominant spontaneous plant was Papaver rhoeas L. (PAPRH) (almost $40 \%$ of the total space was occupied from this plant), followed by Beta vulgaris L. (BEAVX) (almost 25\%).

In terms of the distribution of the weed community during spring in the intra-rows, in the MT treatment, the prevalent species found were Portulaca oleracea (POROL) (13\%) and Cynodon dactylon (CYNDA) (10\%), while the remaining weeds showed a distribution more or less constant along the intra-rows. Regarding the frequency and distribution of the spontaneous flora community in the intra-rows in ZT treatments, Papaver rhoeas (PAPRH) was present in a larger proportion (27\%) compared to the others, followed by Beta vulgaris $(B E A V X)(10 \%)$. The presence of other weed species was similar to that observed in the tillage blocks even if, in the control, Papaver rhoeas (PAPRH) covered about $60 \%$ of the soil.

In the autumn survey, it was observed how the vegetation developed almost exclusively along the rows due to the presence of irrigation, whereas, in the inter-row, a high percentage of bare soil (MT 96\%; ZT 77\%) was registered. Along the row, there was a significant increase in the space occupied by ASC species, particularly sage and lemongrass, and, for both MT and ZT, the most represented spontaneous species was Setaria verticillata (L.) P. Beauv. (SETVE). 
Table 3. List of the spontaneous flora species detected in spring and in autumn in both the inter-row and the intra-row of the experimental field 'long-term trial on organic olive (BiOlea)' at Palazzelli.

\begin{tabular}{|c|c|c|c|c|c|c|c|c|}
\hline \multirow[b]{3}{*}{ Spontaneous Flora Species } & \multirow[b]{3}{*}{ Family } & \multirow[b]{3}{*}{ EPPO Code } & \multicolumn{3}{|c|}{ Spring } & \multicolumn{3}{|c|}{ Autumn } \\
\hline & & & \multicolumn{2}{|c|}{ Inter-Row } & \multirow[b]{2}{*}{$\begin{array}{l}\text { Intra- } \\
\text { Row }\end{array}$} & \multicolumn{2}{|c|}{ Inter-Row } & \multirow[b]{2}{*}{ Intra-Row } \\
\hline & & & $\begin{array}{c}\text { Zero } \\
\text { Tillage }\end{array}$ & $\begin{array}{l}\text { Minimum } \\
\text { Tillage }\end{array}$ & & $\begin{array}{c}\text { Zero } \\
\text { Tillage }\end{array}$ & $\begin{array}{l}\text { Minimum } \\
\text { Tillage }\end{array}$ & \\
\hline Amaranthus retroflexus L. & Amaranthaceae & AMARE & + & + & + & + & + & + \\
\hline Arum maculatum L. & Araceae & ABGMA & - & - & + & - & - & - \\
\hline Avena sterilis L. & Poaceae & AVEST & + & - & + & - & - & - \\
\hline Beta vulgaris L. & Chenopodiaceae & BEAVX & + & + & + & + & + & + \\
\hline Brassica nigra (L.) W.D.J. Koch & Brassicaceae & BRSNI & - & - & + & + & + & - \\
\hline Capsella bursa-pastoris (L.) Medik. & Brassicaceae & CAPBP & - & - & + & + & + & - \\
\hline Convolvolus arvensis L. & Convolvulaceae & CONAR & - & + & + & + & + & - \\
\hline Cynodon dactylon (L.) Pers. & Poaceae & CYNDA & + & + & + & + & + & + \\
\hline Cyperus rotundus L. & Cyperaceae & CYPRO & + & + & + & + & + & + \\
\hline Dactylis glomerata $\mathrm{L}$. & Poaceae & DACGL & + & - & + & - & - & - \\
\hline Digitaria sanguinalis (L.) Scop. & Poaceae & DIGSA & - & - & + & - & - & + \\
\hline Dittrichia viscosa (L.) Greuter & Asteraceae & INUVI & - & - & + & - & - & - \\
\hline Ecballium elaterium (L.) A. Rich. & Cucurbitaceae & ECBEL & - & - & + & - & - & + \\
\hline Elymus repens (L.) Gould & Poaceae & AGGRE & - & - & - & + & + & - \\
\hline Erigeron canadensis L. & Asteraceae & ERICA & - & - & - & - & - & + \\
\hline Euphorbia prostrata Aiton & Euphorbiaceae & EPHPT & - & - & - & - & - & + \\
\hline $\begin{array}{l}\text { Fumaria officinalis L. } \\
\text { Lactuca sativa subsp. serriola (L.) }\end{array}$ & Papaveraceae & FUMOF & + & + & + & + & - & - \\
\hline $\begin{array}{l}\text { Galasso, Banfi, Bartolucci \& } \\
\text { Ardenghi }\end{array}$ & Asteraceae & LACSE & + & + & + & - & - & - \\
\hline Lamium amplexicaule L. & Lamiaceae & LAMAM & - & - & - & - & - & + \\
\hline Lolium perenne L. & Poaceae & LOLPE & + & + & + & - & - & - \\
\hline $\begin{array}{l}\text { Lysimachia arvensis (L.) U. Manns } \\
\text { \& Anderb. }\end{array}$ & Primulaceae & LYSAR & - & - & + & - & - & - \\
\hline Malva sylvestris L. & Malvaceae & MALSY & - & - & + & + & + & - \\
\hline Myosotis arvensis (L.) Hill & Boraginaceae & MYOAR & - & - & + & - & - & - \\
\hline Oxalis pes-caprae $\mathrm{L}$. & Oxalidaceae & OXAPC & - & - & - & - & - & + \\
\hline Papaver rhoeas L. & Papaveraceae & PAPRH & + & + & + & - & - & - \\
\hline Polygonum aviculare L. & Polygonaceae & POLAV & + & + & + & + & + & + \\
\hline Portulaca oleracea $\mathrm{L}$. & Portulacaceae & POROL & + & + & + & + & + & + \\
\hline Ranunculus muricatus L. & Ranunculaceae & RANMU & - & - & + & - & - & - \\
\hline Raphanus raphanistrum $\mathrm{L}$. & Brassicaceae & RAPRA & - & - & + & + & + & + \\
\hline Senecio vulgaris L. & Asteraceae & SENVU & - & - & + & - & - & + \\
\hline Setaria verticillata (L.) P. Beauv. & Poaceae & SETVE & - & - & - & + & + & + \\
\hline Sinapis arvensis L. & Brassicaceae & SINAR & - & - & + & - & - & - \\
\hline Solanum nigrum $\mathrm{L}$. & Solanaceae & SOLNI & - & - & - & - & - & + \\
\hline $\begin{array}{l}\text { Sonchus asper subsp. glaucescens } \\
\text { (Jord.) Ball }\end{array}$ & Asteraceae & SONAR & - & - & - & - & - & + \\
\hline Sonchus oleraceus L. & Asteraceae & SONOL & - & - & - & - & - & + \\
\hline Stellaria media (L.) Vill. & Caryophyllaceae & STEME & - & - & - & - & - & + \\
\hline Triticum spp. & Poaceae & - & - & - & + & - & - & - \\
\hline Urtica dioica L. & Urticaceae & URTDI & - & + & + & - & - & - \\
\hline Veronica peregrina L. & Plantaginaceae & VERPG & - & - & - & - & - & + \\
\hline Total richness (No. species) & & & 12 & 12 & 28 & 14 & 13 & 20 \\
\hline
\end{tabular}

A principal component analysis (PCA) was carried out to evaluate the effect of the ASC on the development, quantity, and distribution of the weed community. With respect to soil management data analysis, Component 1 explained $20.97 \%$ of the total variability, while Component 2 explained 15.71\% (Table 4). According to the PCA results relative to the spring and autumn analysis, as shown in Figure 1A,B for the spring stage, there were no significant differences in terms of distribution between the plots analyzed. Regarding the distribution of the spontaneous flora community in the inter-row with different soil management (ZT and TI) (Figure 1A), weed species appeared divided into four main groups (Figure 1A) characterizing the community: perennial species (namely CONAR, CYNDA, and CYPRO), AMARE, POROL, and DACGL (group 1) were negatively correlated to POLAV, URTDI, BETVU, FUMOF, and LACSE (group 2), and PAPRH (group 3), whereas two completely independent grass species appeared, AVEST and LOLPE (group 4). Despite this, PCA did not show clear differences in terms of abundance and distribution. On the other hand, the zero-tillage community was characterized by the presence of AVEST and LOLPE, whereas BETVU (BEAVX) and URTDI showed a higher relationship with minimum tillage (Figure 2A,C). At this stage (spring), the intra-rows with sage, lemongrass curry plant, and thyme living mulch and control all presented a weed community where all the specimens had an average distribution, with some peak presence of AMARE in sage mulch 
rows and of SETVE in the control row (Figure 2B,D). These records are an overview of 1 year of the field trial and still need to be re-evaluated in the long term management of the orchard. Similar results were obtained for the second assessment in autumn (not shown).

Table 4. (A,B) Principal component analysis (PCA) eigenvalues and percentage variance of the studied samples from experimental trial in relation to the inter-row $(\mathbf{A})$ and intra-row $(\mathbf{B})$ management in spring.

\begin{tabular}{cccccc}
\hline A & \multicolumn{5}{c}{ B } \\
\hline PC & Eigenvalue & \% Variance & PC & Eigenvalue & \% Variance \\
\hline 1 & 3.36 & 20.97 & 1 & 3.02 & 11.17 \\
2 & 2.51 & 15.71 & 2 & 2.38 & 8.80 \\
3 & 2.41 & 15.08 & 3 & 2.15 & 7.95 \\
4 & 1.78 & 11.13 & 4 & 1.87 & 6.93 \\
5 & 1.30 & 8.15 & 5 & 1.53 & 5.67 \\
6 & 1.25 & 7.80 & 6 & 1.49 & 5.50 \\
7 & 1.19 & 7.41 & 7 & 1.39 & 5.17 \\
8 & 0.68 & 4.24 & 8 & 1.26 & 4.67 \\
9 & 0.55 & 3.42 & 9 & 1.13 & 4.17 \\
10 & 0.44 & 2.77 & 10 & 1.12 & 4.14 \\
11 & 0.26 & 1.60 & 11 & 1.04 & 3.86 \\
12 & 0.20 & 1.23 & 12 & 1.01 & 3.76 \\
13 & 0.05 & 0.29 & 13 & 0.94 & 3.49 \\
14 & 0.02 & 0.13 & 14 & 0.89 & 3.30 \\
15 & 0.01 & 0.07 & 15 & 0.85 & 3.16 \\
& & & 16 & 0.77 & 2.86 \\
& & & 17 & 0.71 & 2.62 \\
& & & 18 & 0.65 & 2.39 \\
& & & 19 & 0.58 & 2.14 \\
& & & 20 & 0.52 & 1.93 \\
& & & 21 & 0.38 & 1.42 \\
& & & 22 & 0.35 & 1.30 \\
& & & 25 & 0.26 & 0.97 \\
& & & 0.23 & 0.84 \\
& & & 0.19 & 0.69 \\
& & & 0.16 & 0.58 \\
& & & 0.13 & 0.50 \\
\hline
\end{tabular}




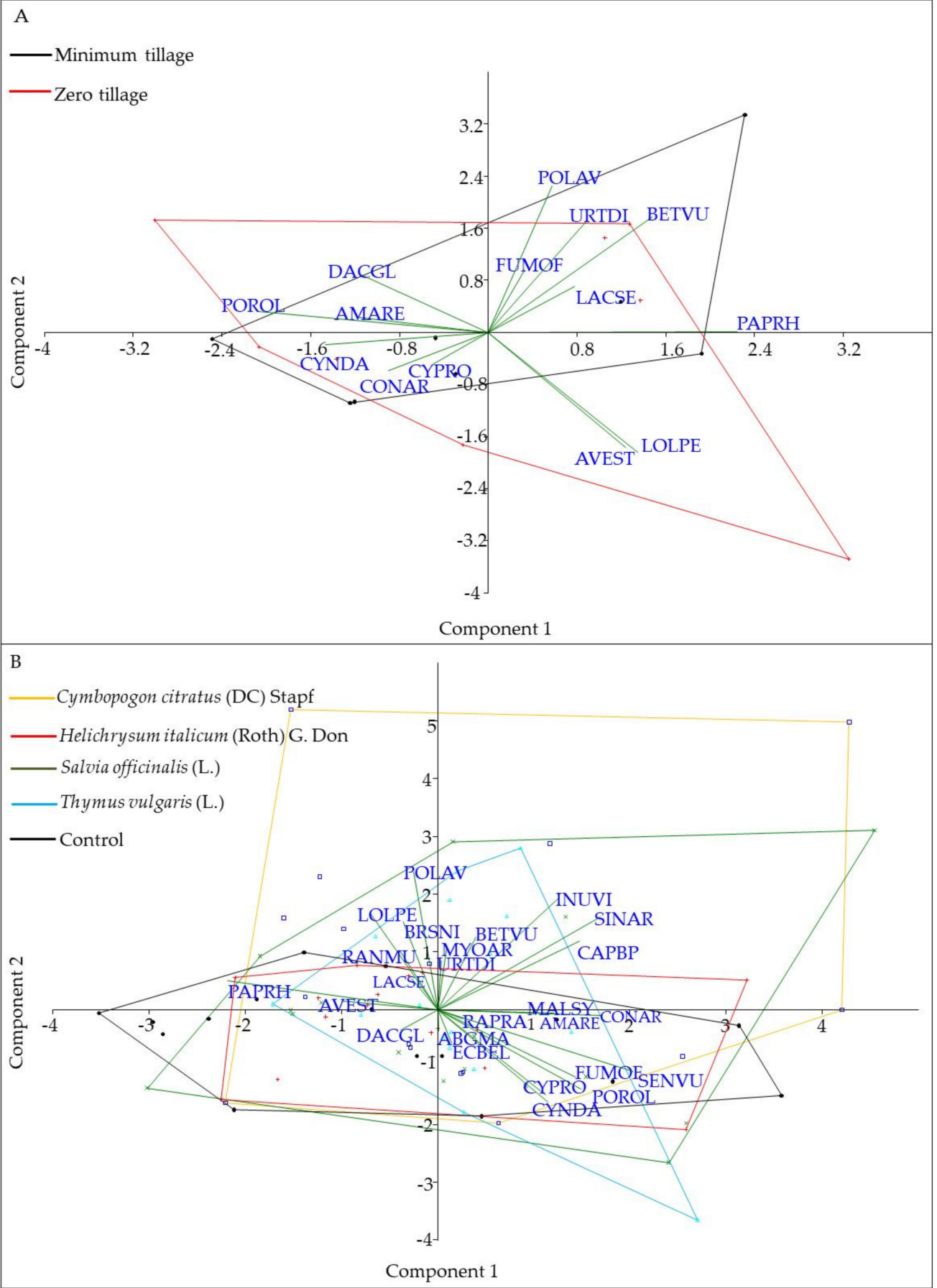

Figure 1. (A,B) Principal component analysis (PCA) ordination diagram (biplot) depicting the localization of the studied samples from the experimental trial in relation to the inter-row (A) and intra-row (B) management. 


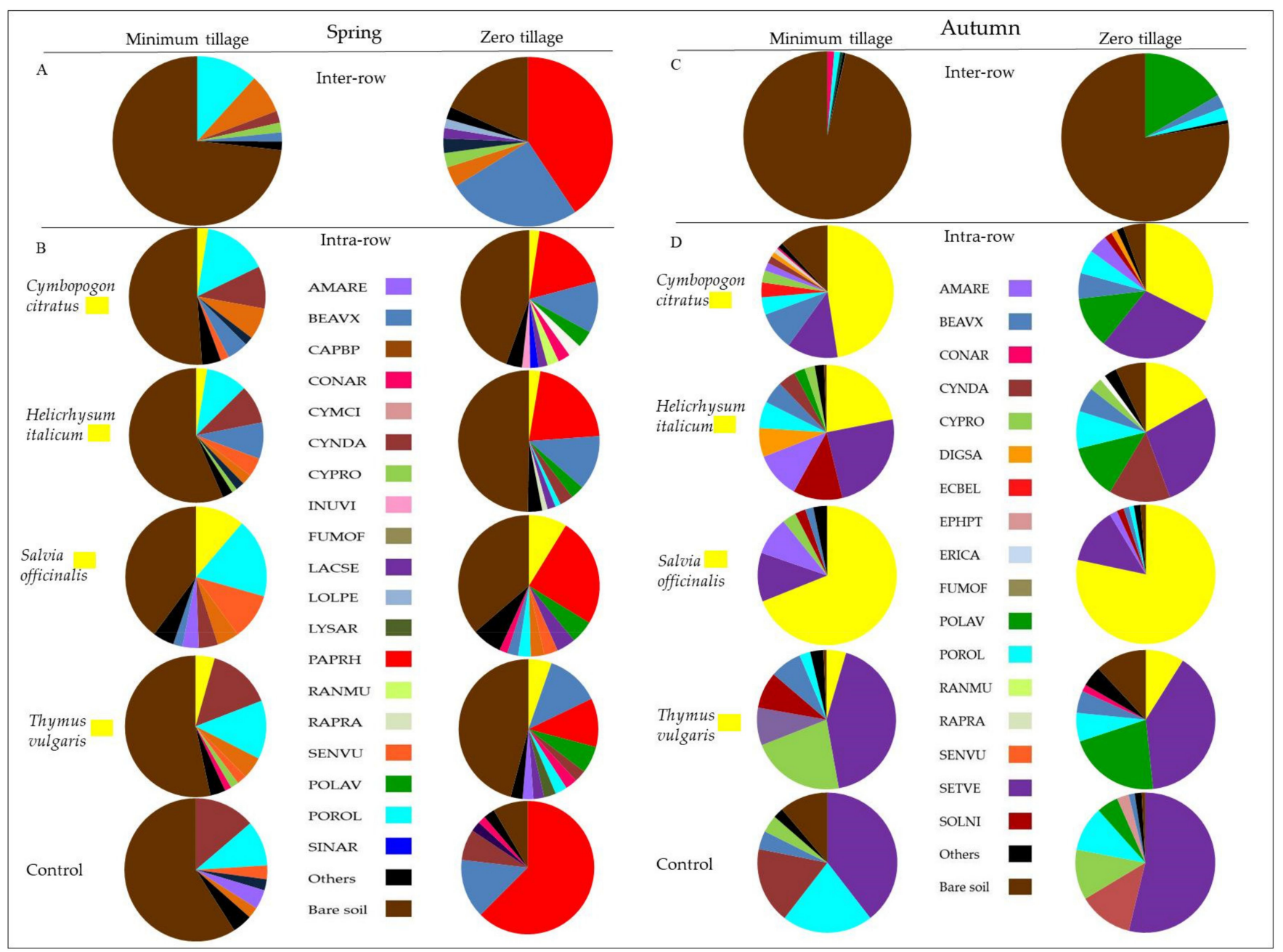

Figure 2. Spontaneous flora species covering percentage in spring (A) and autumn (C) over the interrow and along the intra-row (B,D) of the experimental field 'long-term trial on organic olive (BiOlea)'.

\subsection{Plant Growth Analysis}

In terms of the produced biomass removed with winter pruning (in February), the most abundant quantity was recorded for the NE cultivar in both soil treatments. In September, the quantity of emitted material (suckers and shoots removed from the trunk) was the highest in NE-MT (Figure 3). Concerning the shoot growth monitoring, despite the absence of significant differences among treatments, a better performance for NE in both soil treatments was observed. In general, the growth rate was about $10-12 \mathrm{~cm}$ between day of the year (DOY) 145 and 180, about 8-10 cm between DOY 180 and 210, 2-3 cm between DOY 210 and 239, and $2-3 \mathrm{~cm}$ between DOY 239 and 272 (Figure 4). The plant growth response to the applied soil management is reported in Table 5 . The trunk cross-sectional area reached the highest growth for both cultivars in the zero-tillage soil management. The canopy height increase (approximately $30 \%$ ) was similar among treatments, although NE-ZT showed the highest growth. The trunk cross-sectional area (TCSA) showed more variable results, with NE-ZT and NB-ZT showing the highest growth $(+105 \%$ and $96 \%$, respectively), while NB-TI showed an expansion of about $48 \%$ and NE-TI of just $17 \%$. According to the data presented in Figure 4, all variables had the same rate of growth, with an increase of about 10-12 $\mathrm{cm}$ between DOY 145 and 180, 8-10 $\mathrm{cm}$ between DOY 180 and $210,2-3 \mathrm{~cm}$ between DOY 210 and 239, and $2-3 \mathrm{~cm}$ between DOY 239 and 272. This trend is in accordance with the normal development of the olive trees during their young phase, as well as with the climatic data and water intake registered during the trial. 


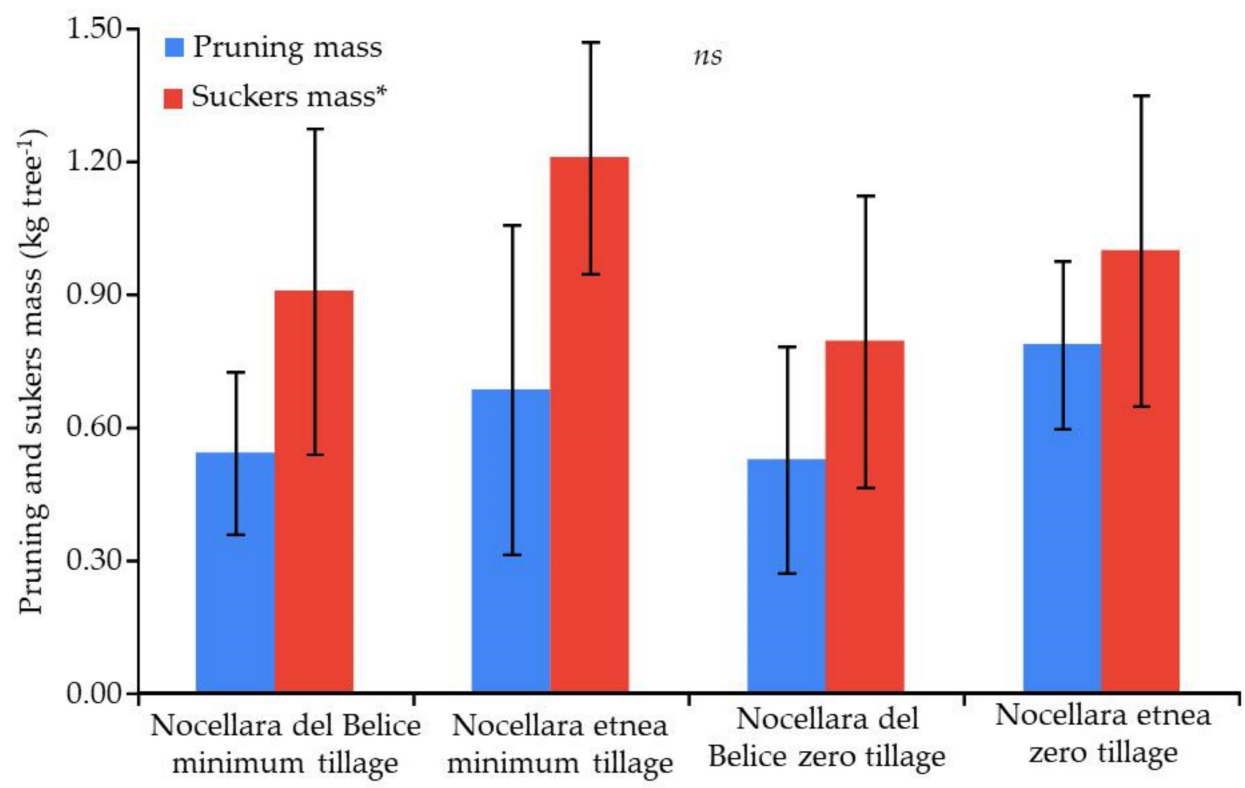

Treatments

Figure 3. Influence of soil management strategy on winter pruning and sucker mass produced ( $\mathrm{ns}=$ not significant within each parameter; bars indicate standard deviation) according to Tukey's HSD test, for each treatment and parameter. * Comprehensive record of the shoots weight grown from the ground level to the branch insertion.

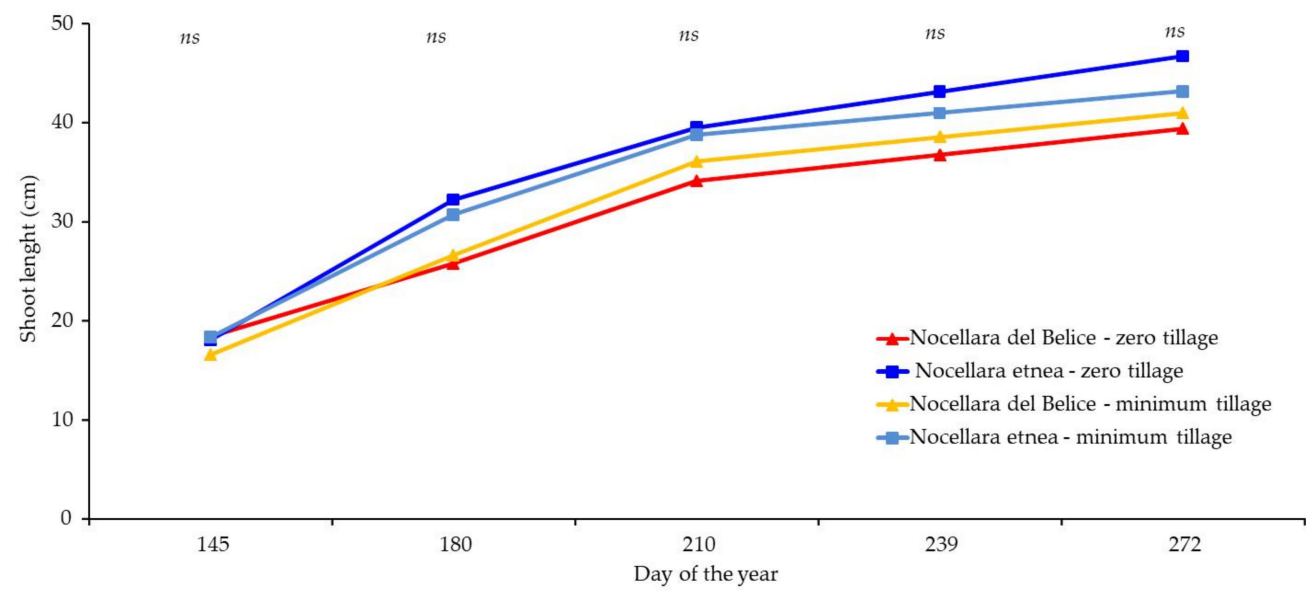

Figure 4. Influence of soil management strategy on mixed shoot growth (ns = not significant) according to Tukey's HSD test, for each treatment and parameter. 
Table 5. Influence of soil management strategy on olive tree growth in pre-growing season on 15 December 2020 as compared with plant growth in autumn on 15 October 2021 and percentage increase. Means indicated by different letters are significantly different (lowercase $p \leq 0.05, \pm$ standard deviation) according to Tukey's HSD test, for each treatment and parameter. ${ }^{n s}=$ not significant.

\begin{tabular}{|c|c|c|c|c|c|c|c|c|c|}
\hline \multirow[b]{2}{*}{ Treatment } & \multicolumn{3}{|c|}{15 December 2020} & \multicolumn{3}{|c|}{15 October 2021} & \multicolumn{3}{|c|}{ Percentage Increase $(\Delta \%)$} \\
\hline & $\begin{array}{c}\text { Trunk Cross- } \\
\text { Sectional Area } \\
\left(\mathrm{cm}^{2}\right)\end{array}$ & $\underset{(\mathrm{cm})}{\text { Canopy Height }}$ & $\begin{array}{c}\text { Canopy } \\
\text { Volume }\left(\mathrm{m}^{3}\right)\end{array}$ & $\begin{array}{c}\text { Trunk Cross- } \\
\text { Sectional Area } \\
\left(\mathrm{cm}^{2}\right)\end{array}$ & $\begin{array}{c}\text { Canopy Height } \\
(\mathrm{cm})\end{array}$ & $\begin{array}{c}\text { Canopy } \\
\text { Volume }\left(\mathrm{m}^{3}\right)\end{array}$ & $\begin{array}{c}\text { Trunk } \\
\text { Cross- } \\
\text { Sectional } \\
\text { Area } \\
(\Delta \%)\end{array}$ & $\begin{array}{c}\text { Canopy } \\
\text { Height } \\
(\Delta \%)\end{array}$ & $\begin{array}{c}\text { Canopy } \\
\text { Volume } \\
(\Delta \%)\end{array}$ \\
\hline $\begin{array}{c}\text { Nocellara } \\
\text { etnea- } \\
\text { minimum } \\
\text { tillage }\end{array}$ & $6.32 \pm 2.4^{\mathrm{ab}}$ & $103.9 \pm 22.06^{\mathrm{a}}$ & $0.29 \pm 0.11^{\mathrm{ns}}$ & $13.7 \pm 2.69^{b}$ & $152.6 \pm 23.43^{\mathrm{ns}}$ & $1.55 \pm 0.38^{\mathrm{a}}$ & 117 & 146 & 542 \\
\hline $\begin{array}{l}\text { Nocellara del } \\
\text { Belice- } \\
\text { minimum } \\
\text { tillage }\end{array}$ & $4.99 \pm 2.09^{b}$ & $72.5 \pm 18.65^{b}$ & $0.21 \pm 0.09 \mathrm{~ns}$ & $12.4 \pm 2.74^{b}$ & $105.8 \pm 22.31^{\mathrm{ns}}$ & $0.73 \pm 0.19^{b}$ & 148 & 145 & 339 \\
\hline $\begin{array}{l}\text { Nocellara } \\
\text { etnea-zero } \\
\text { tillage }\end{array}$ & $8.87 \pm 2.03^{a}$ & $82.6 \pm 31.68^{a b}$ & $0.32 \pm 0.12^{\mathrm{ns}}$ & $18.2 \pm 2.23^{a}$ & $143.1 \pm 29.29^{n s}$ & $1.23 \pm 0.22^{\mathrm{a}}$ & 205 & 173 & 387 \\
\hline $\begin{array}{l}\text { Nocellara del } \\
\text { Belice-zero } \\
\text { tillage }\end{array}$ & $4.13 \pm 2.09 \mathrm{ab}$ & $82.13 \pm 21.65^{a b}$ & $0.34 \pm 0.10^{\mathrm{ns}}$ & $8.1 \pm 3.87^{b}$ & $120.5 \pm 28.20^{\mathrm{ns}}$ & $1.05 \pm 0.19^{b}$ & 196 & 146 & 438 \\
\hline
\end{tabular}

\section{Discussion}

This study focused on three key indicators in agro-ecosystems: (1) the insect community, (2) the spontaneous flora diversity, and (3) the young olive response in terms of vegetative growth. Therefore, in our study, the entire soil-plant-atmosphere continuum (SPAC) was analyzed.

The entomological study was performed in terms of both pollinators and natural enemies. The research was conducted in an olive orchard located on a farm in a district with high relevance for citrus and other fruit crops. The collected Apoidea were observed on 23 species of wild plants, comprising a total of 23 plant genera within 16 plant families (Tables 1 and 2). The Asteraceae family was that frequented by the greatest number of pollinators (15 species), followed by Brassicaceae (12 spp.) and Ranunculaceae (five spp.) (Table 3). On the consociated plants, 39 species of pollinators were observed, 25 on Thymus vulgaris, 12 on Salvia officinalis (Lamiaceae), and nine on Helichrysum italicum (Asteraceae).

Currently, 686 species of bees are known in Sicily [39]. The comparison of bee fauna in the Palazzelli agro-ecosystem evidenced a total of 33 species ( $4.8 \%$ of the species known for the Sicilian fauna) belonging to Colletidae (one species) Andrenidae (seven spp.), Halictidae (four spp.), Megachilidae (five spp.), and Apidae (16 spp.) families.

The order Lepidoptera, the second most important group, was present with 23 species, comprising 16 butterflies and eight moths.

In terms of wild bees, it is significant to note that $72.72 \%$ ( 24 species) of the overall species nest in the ground, and their existence depends on the typology of soil management. In recent years, various regional surveys have focused on the biodiversity of these populations and the agroecological role of these two groups of insects [40-42] or as specific pollinators of crops [43-46].

In order to maintain Apoidea biodiversity, management practices should take into account that most species of wild bees nest in the ground [47], and different agronomic practices, including tillage of the land, usually render crops an unsuitable habitat for wild bees, especially in intensive management [48]. In particular, deep tillage and total removal of spontaneous vegetation represent a serious problem for the foraging and nesting of these pollinators [49]. Therefore, in agricultural environments, wild bees need semi-natural habitats for nesting, obtaining the floral resources, and overwintering. The elements of the landscape, in the field and around the field, also have the function of habitat for fauna in general and, in this context, of ecological corridors in intensely cultivated and biodiversity conservation areas [50,51]. It is also necessary to consider how useful effects are particularly important in Mediterranean agro-ecosystems subject to desertification [52-56]. 
The consociated plants in the intra-row were visited by $62.3 \%$ (43 species) of collected insects, $62.2 \%$ of all pollinators and $62.5 \%$ of all predators. Overall, $15.9 \%$ (11 species) of all reported insects were found only on consociated plants, $16.3 \%$ of pollinators and $12 \%$ of predators.

In our trial, conservative models were also proposed to increase soil fertility and biodiversity (insects and spontaneous flora in the inter-row), reducing the costs for soil management and improving the spontaneous flora control along the row. Our findings evidence small differences between the two soil management strategies. In particular, minimum tillage showed a higher reduction in weed presence at both sampling times (spring and autumn) as confirmed by the higher bare soil cover than in the zero-tillage system (Figure 3). This result evidence how single tillage is an efficient weed management strategy. On the other hand, ZT showed a higher weed cover than MT and a higher richness (data not shown). Nevertheless, ZT in spring showed the selection of perennial species (namely, CONAR, BEAVX, CYPRO, and LOLPE; Figure 2A,C) and a higher characterization of some grass-like species (AVEST and LOLPE; Figure 2B,D). This result is in line with previous findings on zero tillage as a filter to shift the community toward grassy annual and perennial species $[57,58]$, representing a risk in terms of competition with young orchards.

The living mulches realized along the row showed different effects according to the adopted species. In spring, only sage covered the main portion of the soil, due to its habitus. In autumn, 6 months after planting, the sage showed a complete hedgerow, and the consociated flora was observed just at the ground level under the plants. Similarly, lemongrass, despite forming an almost dense hedgerow, completely prevented weed growth under the plants thanks to its strong tillering ability, while allowing growth between plants. Therefore, these species contributed to creating a wide soil cover before the winter season and improved the soil performance [59]. Thyme and curry plant recorded the lowest growth and showed reduced power for competition with the spontaneous flora. However, in these cases, the spontaneous flora had a role in the preservation of the essences during summer since they covered the little plants and permitted them to survive during this season. Perhaps, for these essences, two growing seasons are required to reach a complete hedgerow. Therefore, in the inter-row, lemongrass and sage reduced the need for further soil management. The adopted living mulches reduced the propagation of weeds without reducing the vigor and growth of olive trees. It is possible to assume that the distance from the trunk of the young olive trees to the plants of living mulch was about $40 \mathrm{~cm}$, and it did not significantly affect the olive growth. It is important to highlight that the irrigation lines played a strong role for both the olives trees and the consociated species. Since the olive trees were young, full irrigation was useful to reach high growth rates as shown by the increase registered in morphological parameters (Figures 3 and 4, and Table 5). Among these, the canopy volume exhibited strong growth. According to our findings, it is possible to hypothesize two drip lines for differentiated irrigation between olive trees and living mulch species. From a practical point of view, in areas with hot and dry summers, planting in the field is possible in autumn or in spring. One plant every $50 \mathrm{~cm}$ is enough to boost the growth of the living mulch along the row, but it is important to consider that, after 6 months, the removal of the lines from the row is very difficult; therefore, positioning above the ground level is preferred.

In general, the obtained hedgerows could represent an integrative crop for a secondary income for the farmer, such as food, feed, or industrial products, increasing the resilience of the system to pest incidence and market volatility [60].

\section{Materials and Methods}

\subsection{Site Description, Experimental Design, and Treatments}

The study was carried out between June 2019 and October 2021, in the 'long-term trial on organic olive (BiOlea)', of the experimental farm of the Council for Agricultural Research and Economics (CREA), Research Center for Olive, Tree Fruit, and Citrus located at Palazzelli (Lentini district, Syracuse), Sicily, Italy, (latitude $37.17^{\prime \prime} \mathrm{N}$, longitude $14.50^{\prime \prime}$ 
E, elevation $45 \mathrm{~m}$ a.s.l.). The experiment focused on a young olive orchard, planted with two Sicilian main double aptitude olive cultivars 'Nocellara del Belice' (NB) and 'Nocellara etnea' (NE), grafted onto seedling rootstocks. Trees were planted in May 2019, in northsouth-oriented rows, at a spacing of $6 \mathrm{~m}$ between rows and $5 \mathrm{~m}$ within the row. The adopted training system, since the first winter pruning season (February 2020), was the polyconic vase, aiming to maintain three main branches. Trees were drip-irrigated early in the morning three times per week, from June to September. Irrigation volume scheduling was based on the FAO-56 Penman-Monteith (P-M) approach [61,62], adjusted by the variable crop coefficient $(\mathrm{kc})$ from 0.15 in the first growing season to 0.34 in the second one [63]. Each of the four drippers per tree emitted $2 \mathrm{~L} \cdot \mathrm{h}^{-1}$, for a total of $8 \mathrm{~L} \cdot \mathrm{h}^{-1}$, with an operational pressure of 1 bar. Plants were fully irrigated, corresponding to $95-98 \%$ of crop evapotranspiration, $\mathrm{ET}_{\mathrm{c}}$. The electrical conductivity of the water $\left(\right.$ at $25^{\circ} \mathrm{C}$ ) was $2.02 \mathrm{dS} \cdot \mathrm{m}^{-1}$ and the $\mathrm{pH}$ was 7.30 . Only organic fertilization was applied at the plantation.

The trial was designed as a split-plot system with four blocks of 10 rows with five plants each (Figure 5). The main plot was assigned to soil management practice comparing two systems: (1) minimum tillage (MT) consisting of one tillage $(15 \mathrm{~cm}$ depth) performed at the end of the winter (first week of March) and (2) zero tillage (ZT) consisting of soil managed only through mechanical shredding, performed twice per year: at the end of the winter, in the same period of MT (first week of March), and at the beginning of summer (four week of June). The sub-plot was assigned to the variety alternating a row with NB and a row with NE, so that compared treatments were (1) Nocellara del Belice-minimum tillage (NB-MT), (2) Nocellara del Belice—zero tillage (NB-ZT), (3) Nocellara etnea-minimum tillage (NE-MT), and (4) Nocellara etnea-zero tillage (NE-ZT).

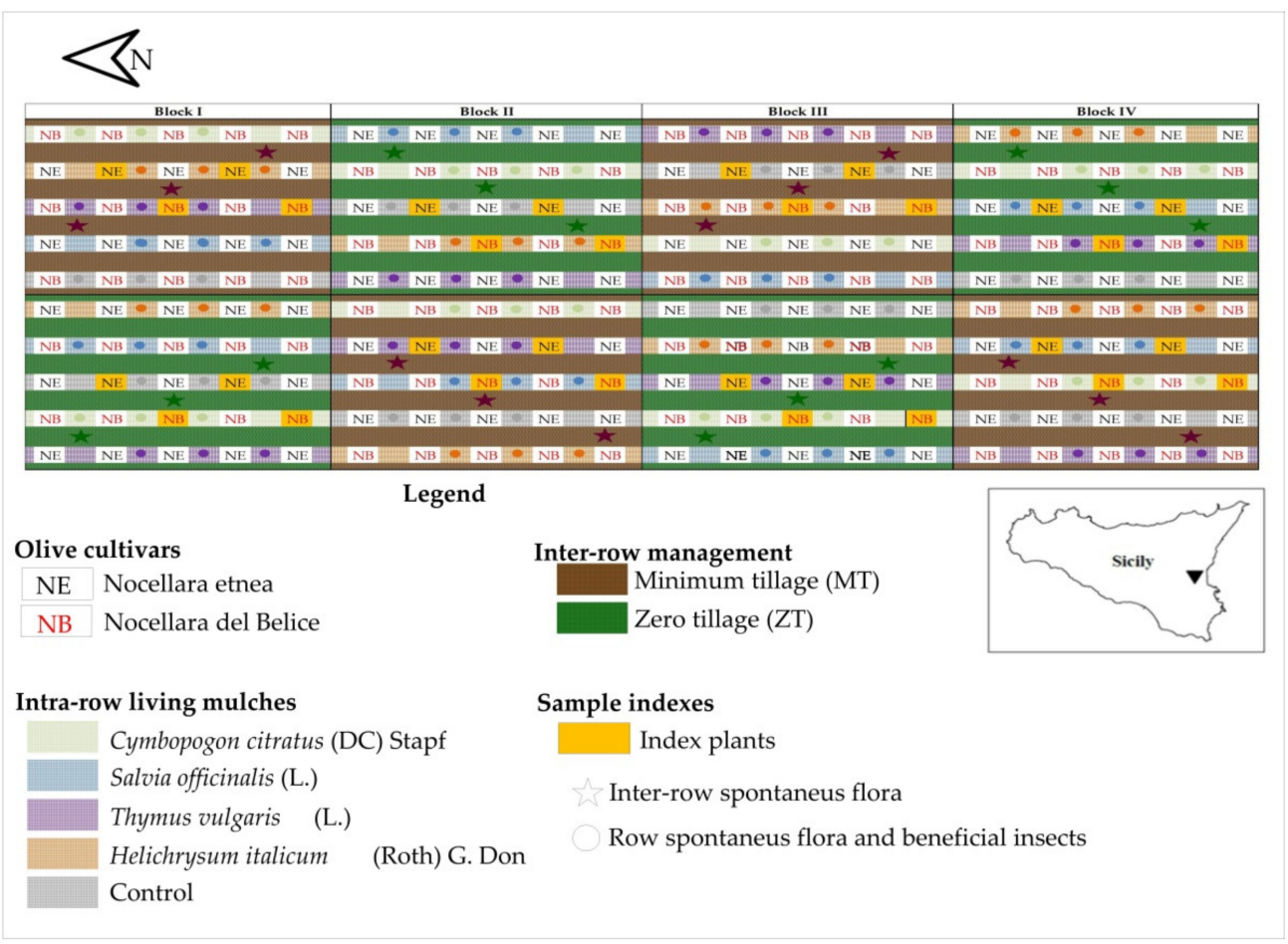

Figure 5. 'Long-term trial on organic olive (BiOlea)' experimental field design within the experimental farm of the CREA, Research Center for Olive, Tree Fruit, and Citrus located at Palazzelli, Sicily, Italy (latitude $37.17^{\prime \prime} \mathrm{N}$, longitude $14.50^{\prime \prime} \mathrm{E}$, elevation $45 \mathrm{~m}$ a.s.l.), with indications of the index plants and the samples points.

For the specific activity of this study, on 15 March 2021, a living mulch system was set down along the row using four officinal species as agro-ecological service crops (ASCs) planted at a distance of $0.5 \mathrm{~m}$ : (1) sage (Salvia officinalis L.), (2) thyme (Thymus vulgaris L.), 
(3) curry plant (Helichrysum italicum (Roth) G. Don), and (4) lemongrass (Cymbopogon citratus (DC) Stapf). No living mulch between trees along the row was used as control (C), but the spontaneous flora was maintained. Inter-row soil management was used as a factor for field spontaneous flora assessment and for plant growth monitoring in both cultivars. The soil management and the living mulch interactions along the row were used both for the spontaneous flora and for the entomological assessments.

\subsection{Soil Analysis and Climatic Data}

At planting, soil characteristics were analyzed at $20-40 \mathrm{~cm}$ depth by three samplings per plot. Soil physical and chemical characteristics are reported in Table 6. Regarding physical characteristics, the quantity and distribution of sand, clay, and silt was obtained by particle-size analysis using the "micro-pipette" method [64]. In terms of chemical properties, total nitrogen $(\mathrm{N})$, organic matter $(\mathrm{OM})$, soil extractable phosphorus (mg/kg), soil exchangeable potassium (meq/100 g), cation exchange capacity, $\mathrm{pH}$, and electrical conductivity (EC) determinations were determined as described in [65-71]. Total nitrogen was measured by Kjeldahl digestion using a Buchi Labortechnik GmbH N analyzer, and organic matter (OM) was measured by quantifying total organic carbon (TOC, $\mathrm{mg}^{\circ} \mathrm{kg}^{-1}$ ). TOC was analyzed by means of elemental analyzer LECO (RC-612; St. Joseph, MI, USA) using a dry combustion method. Soil exchangeable potassium (meq/100 g) was determined in a solution of barium chloride and triethanolamine at $\mathrm{pH} 8.2$ (2 g of soil: $25 \mathrm{~mL})$. Cationic exchange capacity was analyzed by the $\mathrm{BaCl}_{2}$ compulsive exchange method. The $\mathrm{pH}$ and EC determinations were carried out on a HI 9813 portable EC meter (Hanna Instruments, Woonsocket, RI, USA) and an AB 15 pH meter (Thermo Fisher Scientific, Waltham, MA, USA), respectively. Inductively coupled plasma optical emission spectrometry, ICP-OES, was conducted using an Optima 2000 DV, PerkinElmer Inc. Shelton, CT, USA). According to the United States Department of Agriculture (USDA) scheme, the olive-grove soil is classified as loamy sand [72]. The soil $\mathrm{pH}$ is subalkaline, and electrical conductivity is considered low [73].

Table 6. Main soil physical and chemical properties at the experimental field 'long-term trial on organic olive (BiOlea)'.

\begin{tabular}{ccc}
\hline Parameter & Unit Measure & Value \\
\hline Sand & $\%$ & 60 \\
Silt & $\%$ & 21 \\
Clay & $\%$ & 19 \\
pH & & 7.8 \\
Electrical conductivity (1:2.5) & $\mathrm{dS} / \mathrm{m}$ & 0.26 \\
Organic matter & $\%$ & 2.69 \\
Total nitrogen (N) & $\% \mathrm{o}$ & 0.140 \\
Exchangeable phosphorus (P) & $\mathrm{ppm} \mathrm{P}$ & 53 \\
Exchangeable potassium (K) & ppm K & 3628 \\
Cation exchange capacity & meq/100 g & 64.98 \\
(CEC) & & \\
\hline
\end{tabular}

Climatic data, namely, monthly minimum, mean, and maximum air temperature, global solar radiation, rainfall, reference evapotranspiration $\left(\mathrm{ET}_{0}\right)$, cultural evapotranspiration $\left(\mathrm{ET}_{\mathrm{C}}\right)$, and vapor pressure deficit, registered at the experimental field, were collected from an agro-meteorological station located in the experimental farm (Figure 6). The climate of the region is typical Mediterranean, with hot and dry summers. According to the available meteorological data (30 years, not shown), annual mean reference rainfall is about $550 \mathrm{~mm}$, and the maximum temperature in summer during daytime often reaches $38-40{ }^{\circ} \mathrm{C}$ [74]. During the trial, the site's climate was characterized by mild and wet winters, while the summers were semiarid (first and second) and dry (third) in which no rainfall was recorded from May to August. The annual average temperature was 
$18.29^{\circ} \mathrm{C}$. The lowest minimum temperatures were recorded in January and February. Mean temperature values were always above $22^{\circ} \mathrm{C}$ from April to November.

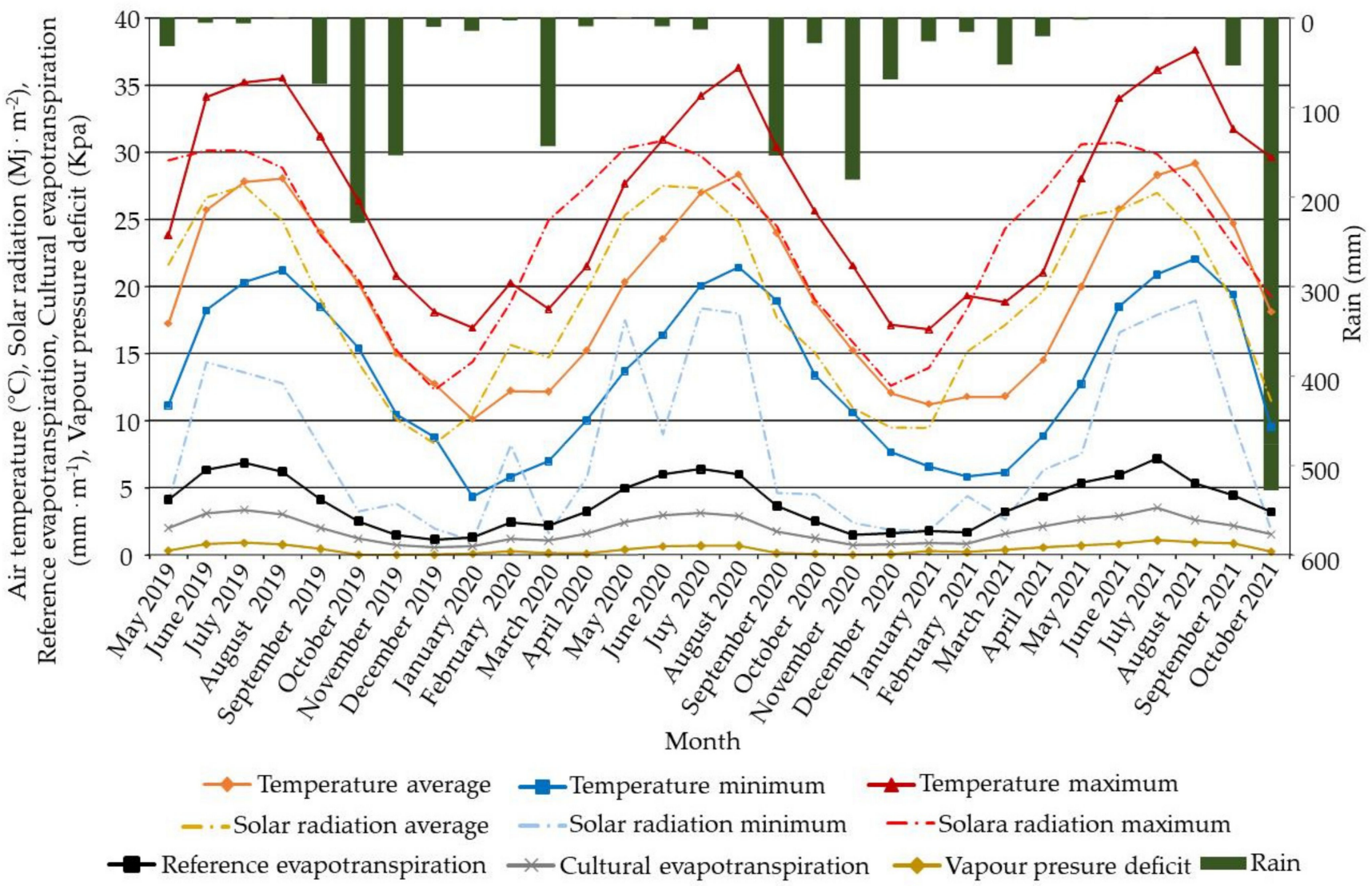

Figure 6. Monthly minimum, average, and maximum air temperature and solar radiation, rainfall, reference and cultural evapotranspiration, and vapor pressure deficit registered in the experimental field 'long-term trial on organic olive (BiOlea)'.

\subsection{Entomological Samplings and Analysis}

Entomological studies, regarding pollinators (Hymenoptera Apoidea, Lepidoptera, and Diptera Syrphidae) and predator insects (Neuroptera and Coleoptera Coccinellidae), were carried out twice per month, from March 2020 to October 2021. In particular, from 1 March 2020 to 28 February 2021, insects were collected from $2500 \mathrm{~m}^{2}$ for each of the two soil management areas $\left(125 \mathrm{~m}^{2}\right.$ each inter-row $\times 5$ rows $\times 4$ blocks $\left.=2500 \mathrm{~m}^{2}\right)$ for a total of $5000 \mathrm{~m}^{2}$. From 1 March 2021 to 31 October 2021, a defined linear transect of $25 \mathrm{~m}$ each in eight replicates $(25.8=200 \mathrm{~m})$ was used for the assessments of the beneficial insects along the row.

Specimens were collected with the net technique, from 10:00 a.m. to 4:00 p.m., on flowers (pollinators) and vegetative organs (predators) of the spontaneous and planted (intercropping) plant species. All specimens were transferred in the laboratory, dry prepared, and identified, when necessary, through the observation of sexual structures. The month of collection, number of specimens, and visited plants are given for all species. Specimens of wild bees were identified using the taxonomic keys in [75-77], as Lepidoptera [78], Diptera Syrphidae [38], Coleoptera Coccinellidae [79,80], and Neuroptera [81]. The classification followed Michener [47] for supra-specific taxa, and their nomenclature was according to $[82,83]$. The examined specimens were preserved in the collections of the authors and in the entomological collection of CREA-OFA of Acireale. 


\subsection{Spontaneous Flora Assessment and Analysis}

Weed abundance and community composition and diversity were evaluated and monitored twice during the experiment: at the start of spring on 25 March 2021 and in autumn on 6 October 2021 at day of the year (DOY) 141 and 255, respectively, corresponding to the stages of maximum development of the natural cover (i.e., spring and autumn). At each sampling stage, weed cover (i.e., the percentage of the surface area of the quadrat covered by weeds) was evaluated at a species level by randomly placing three $1.0 \mathrm{~m}^{2}$ quadrats within each block per soil management in the inter-row ( 3 squares $\times 4$ subplots $\times 2$ soil managements $=24$ ) and three $1.0 \mathrm{~m}^{2}$ quadrats for each intercropping species in each intra-row, in all blocks for each soil management ( 3 squares $\times 5$ consociated species or control $\times 4$ subplots $\times 2$ soil managements $=120$ ). Density was evaluated by placing two $0.60 \times 0.60 \mathrm{~m}^{2}$ quadrats in the intra-row space and four $0.25 \times 0.25 \mathrm{~m}^{2}$ quadrats in each soil management system per block. Cover and density assessment allowed providing the total cover $(\%)$ and the total density of the community.

\subsection{Tree Growth Monitoring}

Biometrical measurements of the young olive trees were conducted on 15 December 2020 and on 15 October 2021, and the relative increments were calculated. Measurements regarded the total height of the tree, the widths of the canopy (in two perpendicular directions from the projection on the ground at noon), and the canopy height, measured from the first primary branch insertion point to the top. The canopy volume was calculated assuming an elliptical shape [84]. The trunk cross-sectional area (TCSA) was calculated from the trunk circumference measured at $20 \mathrm{~cm}$ from the ground.

Pruning was realized on 15 February 2020, and the weight of the removed material was recorded, while the weight per tree of new emitted suckers was recorded in October 2021.

Moreover, the total vegetative growth was obtained by measuring the length improvement from the beginning of the vegetative growth (15 April 2021) to the end of the experiment (31 October 2021) of two 1 year old mixed shoots per plants, randomly selected and labeled around the canopy of the trees at 1.0-1.2 m height from the ground.

\subsection{Statistical Analysis}

Analysis of variance (ANOVA) was performed with Jamovi 2.0.0 statistical software (The jamovi project, 2021). One-way analysis of variance (ANOVA) was carried out on the differences among the canopy treatments. A post hoc analysis based on Tukey's HSD test (Tukey's honestly significant difference) was performed at a significance level ( $p$-value) of $0.05,0.01$, and 0.001 , respectively. Principal component analysis (PCA) was performed with Past 4.03 statistical software (Oyvind Hammer), to assess the effect of the ASC along the row, as well as the role of tillage used in the inter-row soil management in the development, abundance, and distribution of the weed community in spring and in autumn.

\section{Conclusions}

The obtained results, even if preliminary, evidence the role of diversification strategies in recovering rather than halting the loss of wild biodiversity in agricultural fields. In particular, the agronomical techniques proposed for the young organic olive, have been shown to be an evaluable option for promoting the presence of pollinators and, thus, supporting the potential production. The inter-row management resulted in a diversified spontaneous flora community, more service provider than competitor. In addition, the wild plants on the row had a sheltering effect on the living mulch species during the hot period, demonstrating a flow of services between the components of the agroecosystem. Among the studied living mulch species, sage and lemongrass were able to create an almost continuous hedge along the row and a semi-full soil cover, thus reducing the need for weed management in the intra-row soil strip and improving the beneficial insects without influencing the plant growth. 
In a nutshell, current results indicated that the agroecological practices adopted increase the richness of the biota and, hence, the complexity of the Arthropod fauna in terms of number of species and taxonomic complexity. The knowledge of the two groups of insects investigated is of primary importance for evaluating the local populations of pollinators and predators of wild and cultivated plants.

Author Contributions: Conceptualization, F.F., C.C. and S.B.; methodology, F.F., E.M.L., C.C. and V.I.; validation, G.L.C., R.C. and E.N.; formal analysis, F.F., S.B., C.C., G.L.C. and E.N.; investigation, B.T., R.C. and A.G.; resources, F.F., G.L.C. and S.B.; data curation, V.I., A.G. and R.C.; writing-original draft preparation, F.F., S.B., E.M.L., C.C., G.L.C., A.G. and V.I.; writing-review and editing, F.F., S.B., C.C., G.L.C., E.M.L. and E.N.; visualization, F.F., B.T. and V.I.; supervision, F.F. and C.C.; project administration, F.F., E.M.L. and C.C.; funding acquisition, F.F. All authors have read and agreed to the published version of the manuscript.

Funding: This study was carried out within the project "Promozione e rafforzamento de dispositivi di lungo periodo in agricoltura biologica-PERILBIO" (Decree n. 3400, 20 December 2018; n. 92011 20 December 2018) funded by the Italian Ministry of Agriculture (MiPAAF).

Institutional Review Board Statement: Not applicable.

Informed Consent Statement: Not applicable.

Data Availability Statement: All data are available via email request to the corresponding authors.

Acknowledgments: The authors thank "G.S. S.p.A. Group Italia" for the economic support in publishing this study through the agreement "Azioni di studio e divulgazione finalizzate alla riduzione e ottimizzazione dell'uso di agrofarmaci in coltivazioni di pesche e nettarine, e all'individuazione di buone pratiche agronomiche al fine di preservare l'ambiente e le api (GS PES-NET21)" subscribed on 13 November 2020. We also wish to thank Vittorio Nobile (Ragusa, Italy) for confirming the determination of some species of Hymenoptera Apoidea.

Conflicts of Interest: The authors declare no conflict of interest. The funders had no role in the design of the study; in the collection, analyses, or interpretation of data; in the writing of the manuscript; or in the decision to publish the results.

\section{References}

1. Montanarella, L.; Panagos, P. The relevance of sustainable soil management within the European Green Deal. Land Use Policy 2021, 100, 104950. [CrossRef]

2. Alexandratos, N.; Bruinsma, J. World Agriculture towards 2030/2050: The 2012 Revision; ESAWorking Paper No. 12-03; FAO: Rome, Italy, 2012.

3. Food and Agriculture Organization. 2050: A Third More Mouths to Feed. 2009. Available online: http://www.fao.org/news/ story/en/item/35571/icode/ (accessed on 1 September 2021).

4. Ciaccia, C.; Testani, E.; Fiore, A.; Iocola, I.; Di Pierro, M.; Mele, G.; Ferlito, F.; Cutuli, M.; Montemurro, F.; Farina, R.; et al. Organic Agroforestry Long-Term Field Experiment Designing Trough Actors' Knowledge towards Food System Sustainability. Sustainability 2021, 13, 5532. [CrossRef]

5. Michalopoulos, G.; Kasapi, K.A.; Koubouris, G.; Psarras, G.; Arampatzis, G.; Hatzigiannakis, E.; Kavvadias, V.; Xiloyannis, C.; Montanaro, G.; Malliaraki, S.; et al. Adaptation of Mediterranean Olive Groves to Climate Change through Sustainable Cultivation Practices. Climate 2020, 8, 54. [CrossRef]

6. Gómez, J.A.; Amato, M.; Celano, G.; Koubouris, G.C. Organic olive orchards on sloping land: More than a specialty niche production system? J. Environ. Manag. 2008, 89, 99-109. [CrossRef] [PubMed]

7. Stroosnijder, L.; Mansinho, M.I.; Palese, A.M. OLIVERO: The project analysing the future of olive production systems on sloping land in the Mediterranean basin. J. Environ. Manag. 2008, 89, 75-85. [CrossRef] [PubMed]

8. Beaufoy, G. EU Policies for Olive Farming: Unsustainable on All Counts; WWF Europe/Birdlife International: Brussels, Belgium, 2001; p. 16.

9. Connor, D.J.; Gomez-del-Campo, M.; Rousseaux, M.C.; Searles, P.S. Structure, management and productivity of hedgerow olive orchards: A review. Sci. Hortic. 2014, 169, 71-93. [CrossRef]

10. Tous, J. Olive production systems and mechanization. Acta Hortic. 2011, 924, 169-184. [CrossRef]

11. Caruso, G.; Palai, G.; Marra, F.P.; Caruso, T. High-Resolution UAV Imagery for Field Olive (Olea europaea L.) Phenotyping. Horticulturae 2021, 7, 258. [CrossRef]

12. Assirelli, A.; Romano, E.; Bisaglia, C.; Lodolini, E.M.; Neri, D.; Brambilla, M. Canopy Index Evaluation for Precision Management in an Intensive Olive Orchard. Sustainability 2021, 13, 8266. [CrossRef] 
13. Neri, D.; Cioccolanti, T.; Zuccherelli, G.; Navacchi, O.; Giorgi, V.; Lodolini, E.M. Micropropagation effects on juvenile traits, flower differentiation, and tree architecture in young olive trees. Agronomy 2020, 10, 1742. [CrossRef]

14. The International Olive Oil Council. 2016. Available online: http:/ / www.internationaloliveoil.org (accessed on 15 September 2021).

15. Eurostat. Agriculture, Forestry and Fishery Statistics, 2014 ed.; Eurostat: Luxembourg, 2015.

16. De Graaff, J.; Eppink, L.A.A.J. Olive oil production and soil conservation in southern Spain, in relation to EU subsidy policies. Land Use Policy 1999, 16, 259-267. [CrossRef]

17. Potts, S.G.; Petanidou, T.; Roberts, S.; O'Toole, C.; Hulbert, A.; Willmer, P. Plant-pollinator biodiversity and pollination services in a complex Mediterranean landscape. Biol. Conserv. 2006, 129, 519-529. [CrossRef]

18. Palese, A.M.; Vignozzi, N.; Celano, G.; Agnelli, A.E.; Pagliai, M.; Xiloyannis, C. Influence of soil management on soil physical characteristics and water storage in a mature rainfed olive orchard. Soil Tillage Res. 2014, 144, 96-109. [CrossRef]

19. Wagner, D.L. Insect Declines in the Anthropocene. Annu. Rev. Entomol. 2020, 65, 457-480. [CrossRef] [PubMed]

20. Nieto, A.; Roberts, S.P.M.; Kemp, J.; Rasmont, P.; Kuhlmann, M.; García Criado, M.; Biesmeijer, J.C.; Bogusch, P.; Dathe, H.H.; De la Rúa, P.; et al. European Red List of Bees; Publication Office of the European Union: Luxembourg, 2014; p. 84p.

21. Palm, C.; Blanco-Canqui, H.; DeClerck, F.; Gatere, L.; Grace, P. Conservation agriculture and ecosystem services: An overview. Agric. Ecosyst. Environ. 2014, 187, 87-105. [CrossRef]

22. Ciaccia, C.; Testani, E.; Roccuzzo, G.; Canali, S. The role of agrobiodiversity in sustainable food systems design and management. In Genetic Diversity in Horticultural Plants; Springer: Cham, Switzerland, 2019; pp. 245-271.

23. Landis, D.A. Designing agricultural landscapes for biodiversity-based ecosystem services. Basic Appl. Ecol. 2017, 18, 1-12. [CrossRef]

24. Wood, S.A.; Karp, D.S.; DeClerck, F.; Kremen, C.; Naeem, S.; Palm, C.A. Functional traits in agriculture: Agrobiodiversity and ecosystem services. Trends Ecol. Evol. 2015, 30, 531-539. [CrossRef]

25. Canali, S.; Diacono, M.; Campanelli, G.; Montemurro, F. Organic No-Till with Roller Crimpers: Agro-ecosystem Services and Applications in Organic Mediterranean Vegetable Productions. Sustain. Agric. Res. 2015, 4, 70-79. [CrossRef]

26. Bommarco, R.; Kleijn, D.; Potts, S.G. Ecological intensification: Harnessing ecosystem services for food security. Trends Ecol. Evol. 2013, 28, 230-238. [CrossRef]

27. Ramos, M.E.; Benítez, E.; García, P.A.; Robles, A.B. Cover crops under different managements vs. frequent tillage in almond orchards in semiarid conditions: Effects on soil quality. Appl. Soil. Ecol. 2010, 44, 6-14. [CrossRef]

28. Nieto, O.M.; Castro, J.; Fernandez-Ondono, E. Conventional tillage versus cover crops in relation to carbon fixation in Mediterranean olive cultivation. Plant Soil 2013, 365, 321-335. [CrossRef]

29. Mourugàn-Coronado, A.; Linares, C.; Gòmez-Lòpeez, M.D.; Faz, A.; Zornova, R. The impact of intercropping, tillage and fertilizer type on soil and crop yield in fruit orchards under Mediterranean conditions: A meta-analysis of field studies. Agric. Syst. 2020, 178, 102736. [CrossRef]

30. Sestini, A. Il Paesaggio; Club Italiano: Milano, Italy, 1963.

31. Paris, P.; Camilli, F.; Rosati, A.; Mantino, A.; Mezzalira, G.; Dalla Valle, C.; Franca, A.; Seddaiu, G.; Pisanelli, A.; Lauteri, M.; et al. What is the future for agroforestry in Italy? Agroforest Syst. 2019, 93, 2243-2256. [CrossRef]

32. Nicolosi, E.; Ferlito, F.; Allegra, M.; Cicala, A.; Trovato, F.; La Malfa, S. Influences of aspect and tillage on two winegrape cultivars on Mount Etna. N. Z. J. Crop Hortic. Sci. 2016, 44, 83-102. [CrossRef]

33. Ferlito, F.; Allegra, M.; Torrisi, B.; Pappalardo, H.; Gentile, A.; La Malfa, S.; Continella, A.; Stagno, F.; Nicolosi, E. Early defoliation effect on water status, fruit yield and must quality of 'Nerello mascalese' grapes. Sci. Agric. 2020, 77, 1-10. [CrossRef]

34. Nicolosi, E.; Iovino, V.; Distefano, G.; Di Guardo, M.; La Malfa, S.; Gentile, A.; Palliotti, A.; Las Casas, G.; Ferlito, F. Mid-Term Effects of Conservative Soil Management and Fruit-Zone Early Leaf Removal Treatments on the Performance of Nerello Mascalese (Vitis vinifera L.) Grapes on Mount Etna (Southern Italy). Agronomy 2021, 11, 1070. [CrossRef]

35. Bennici, S.; Las Casas, G.; Distefano, G.; Di Guardo, M.; Continella, A.; Ferlito, F.; Gentile, A.; La Malfa, S. Elucidating the contribution of wild related species on autochthonous pear germplasm: A case study from Mount Etna. PLoS ONE 2018, 13, e0198512. [CrossRef]

36. Russo, C.; Cappelletti, G.M.; Nicoletti, G.M.; Di Noia, A.E.; Michalopoulos, G. Comparison of European Olive Production Systems. Sustainability 2016, 8, 825. [CrossRef]

37. Magdoff, F. Ecological agriculture: Principles, practices, and constraints. Renew. Agric. Food Syst. 2007, 22, 109-117. [CrossRef]

38. Burgio, G.; Sommaggio, D.; Birtele, D. I Sirfidi (Ditteri): Biodiversità e conservazione. In Manuali e Linee Guida; ISPRA: Roma, Italy, 2015; Volume 128, p. 182.

39. Comba, M. Hymenoptera: Apoidea: Anthophila of Italy. 2021. Available online: http://digilander.libero.it/mario.comba (accessed on 27 July 2021).

40. Mazzeo, G.; Bella, S.; Seminara, A.R.; Longo, S. Bumblebees in natural and agro-ecosystems at different altitudes from Mount Etna, Sicily (Hymenoptera Apidae Bombinae): Long-term faunistic and ecological observations. Redia 2015, XCVIII, $123-131$.

41. Mazzeo, G.; Longo, S.; Seminara, A.R.; Bella, S. Faunistic and ecological studies on Apidae (Hymenoptera, Apoidea) in natural and cultivated ecosystems in Sicily. Redia 2019, 102, 153-162. [CrossRef]

42. Bella, S.; Catania, R.; Nobile, V.; Mazzeo, G. New or little known bees (Hymenoptera, Apoidea) from Sicily. Fragm. Entomol. 2020, 52, 113-117. [CrossRef] 
43. Incalcaterra, G.; Iapichino, G.; D'Anna, F.; Sinacori, A. Influences of different Pollinators on Winter Melon Grown under Polyethylene Tunnel. Acta Hort. 2003, 614, 297-299. [CrossRef]

44. Lo Verde, G.; La Mantia, T. The role of native flower visitors in pollinating Opuntia ficus-indica (L.) Mill. naturalized in Sicily. Acta Oecol. 2011, 37, 413-417. [CrossRef]

45. Mazzeo, G.; Scavo, A.; Lo Monaco, A.; Longo, S.; Mauromicale, G. Insect pollinators improve seed production in globe artichoke (Cynara cardunculus var. scolymus). Ann. Appl. Biol. 2020, 176, 241-248. [CrossRef]

46. Bella, S.; Catania, R.; Baviera, C. First record of the genus Serangium Blackburn, 1889 (Coleoptera Coccinellidae) in Italy. Redia 2021, 104, 185-191. [CrossRef]

47. Michener, C.D. The Bees of the World, 2nd ed.; John Hopkins University Press: Baltimore, MD, USA, 2007 ; p. 953.

48. Holzschuh, A.; Steffan-Dewenter, I.; Kleijn, D.; Tscharntke, T. Diversity of flower-visiting bees in cereal fields: Effects of farming system, landscape composition and regional context. J. Appl. Ecol. 2007, 44, 41-49. [CrossRef]

49. Scheper, J.A. Promoting wild bees in European agricultural landscapes. The Role of Floral Resources in Driving and Mitigating Wild Bee Decline; Alterra, Wageningen University \& Research Centre: Wageningen, The Netherlands, 2015; 175p.

50. Wezel, A.; Casagrande, M.; Celette, F.; Vian, J.-F.; Ferrer, A.; Peigné, J. Agroecological practices for sustainable agriculture. A review. Agron. Sustain. Dev. 2014, 34, 1-20. [CrossRef]

51. Baviera, C.; Bellavista, M.; Altadonna, G.; Turrisi, G.F.; Bella, S.; Muscarella, C.; Sparacio, I. The Cerambycidae (Coleoptera: Chrysomeloidea) of Sicily: Recent records and updated checklist. AAPP Atti Accad. Peloritana dei Pericolanti Cl. Sci. Fis. Mat. Nat. 2017, 95, 2.

52. Ramos, M.E.; Robles, A.B.; Sánchez-Navarro, A.; González-Rebollar, J.L. Soil responses to different management practices in rainfed orchards in semiarid environments. Soil Tillage Res. 2011, 112, 85-91. [CrossRef]

53. Koch, J.B.; Lozier, J.; Strange, J.P.; Ikerd, H.; Griswold, T.; Cordes, N.; Solter, L.; Stewart, I.; Cameron, S.A. USBombus, a database of contemporary survey data for North American Bumble Bees (Hymenoptera, Apidae, Bombus) distributed in the United States. Biodivers. Data J. 2015, 3, e6833. [CrossRef] [PubMed]

54. Taguas, E.V.; Gómez, J.A. Vulnerability of olive orchards under the current CAP (Common Agricultural Policy) regulations on soil erosion: A study case in Southern Spain. Land Use Policy 2015, 42, 683-694. [CrossRef]

55. Almagro, M.; de Vente, J.; Boix-Fayós, C.; García-Franco, N.; de Aguilar, J.M.; González, D.; Solé-Benet, A.; Martínez-Mena, M. Sustainable land management practices as providers of several ecosystem services under rainfed Mediterranean agroecosystems. Mitig. Adapt. Strateg. Glob. Chang. 2016, 21, 1029-1043. [CrossRef]

56. Chamizo, S.; Serrano-Ortiz, P.; López-Ballesteros, A.; Sánchez-Cañete, E.P.; Vicente-Vicente, J.L.; Kowalski, A.S. Net ecosystem CO2 exchange in an irrigated olive orchard of SE Spain: Influence of weed cover. Agric. Ecosyst. Environ. 2017, 239, 51-64. [CrossRef]

57. Armengot, L.; Berner, A.; Blanco-Moreno, J.M.; Mäder, P.; Sans, F.X. Long-term feasibility of reduced tillage in organic farming. Agron. Sustain. Develop. 2015, 35, 339-346. [CrossRef]

58. Nichols, V.; Verhulst, N.; Cox, R.; Govaerts, B. Weed dynamics and conservation agriculture principles: A review. Field Crops Res. 2015, 183, 56-68. [CrossRef]

59. Mia, M.J.; Massetani, F.; Murri, G.; Neri, D. Sustainable alternatives to chemicals for weed control in the orchard a review. Hortic. Sci. 2020, 47, 1-12. [CrossRef]

60. Bateni, S.; Vosoughifar, H.; Ek, M.; Xu, T. Estimation of Daily Reference Evapotranspiration from Limited Climatic Variables in Coastal Regions. In Proceedings of the AGU Fall Meeting, San Francisco, CA, USA, 9-13 December 2019; American Geophysical Union: Washington, DC, USA, 2019.

61. Allen, R.G.; Pereira, L.S.; Raes, D.; Smith, M. Crop Evapotranspiration. In Guidelines for Computing Crop Water Requirements; FAO Irrigation and Drainage Paper; FAO: Rome, Italy, 1998; Volume 56, p. 300.

62. Saitta, D.; Vanella, D.; Ramírez-Cuesta, J.M.; Longo-Minnolo, G.; Ferlito, F.; Consoli, S. Comparison of Orange Orchard Evapotranspiration by Eddy Covariance, Sap Flow, and FAO-56 Methods under Different Irrigation Strategies. J. Irrig. Drain. 2020, 146, 05020002. [CrossRef]

63. Lo Cicero, L.; Puglisi, I.; Nicolosi, E.; Gentile, A.; Ferlito, F.; Continella, A.; Lo Piero, A.R. Anthocyanin levels and expression analysis of biosynthesis-related genes during ripening of sicilian and international grape berries subjected to leaf removal and water deficit. J. Agric. Sci. 2016, 18, 1333-1344.

64. Miller, W.P.; Miller, D.M. A micro-pipette method for soil mechanical analysis. Commun. Soil Sci. Plant Anal. 1987, 18, 1-15. [CrossRef]

65. Ferlito, F.; Torrisi, B.; Allegra, M.; Stagno, F.; Caruso, P.; Fascella, G. Evaluation of Conifer Wood Biochar as Growing Media Component for Citrus Nursery. Appl. Sci. 2020, 10, 1618. [CrossRef]

66. Torrisi, B.; Allegra, M.; Amenta, M.; Gentile, F.; Rapisarda, P.; Fabroni, S.; Ferlito, F. Physico-chemical and multielemental traits of anaerobic digestate from Mediterranean agro-industrial wastes and assessment as fertiliser for citrus nurseries. Waste Manag. 2021, 131, 201-213. [CrossRef] [PubMed]

67. Ferlito, F.; Distefano, G.; Gentile, A.; Allegra, M.; Lakso, A.N.; Nicolosi, E. Scion-rootstock interactions influence the growth and behaviour of the grapevine root system in a heavy clay soil. Aust. J. Grape Wine Res. 2020, 26, 68-78. [CrossRef]

68. Olsen, S.; Cole, C.; Watanabe, F.; Dean, L. Estimation of Available Phosphorus in Soils by Extraction with Sodium Bicarbonate (Circular No. 939); United States Department of Agriculture: Washington, DC, USA, 1954. 
69. Sumner, M.E.; Miller, W.P. Cation exchange capacity and exchange coefficients. In Methods of Soil Analysis; Sparks, D.L., Ed.; Part 3, Chemical Methods; Book Series No. 5; Soil Science Society of America: Madison, WI, USA, 1996.

70. Springer, U.; Klee, J. Prufung der Leistungsfahigkeit von einigen wichtigeren Verfahren zur Bestimming des Kohlemstoffs mittels Chromschwefelsaure sowie Vorschlag einer neuen Schnellmethode. Z. Pflanz. Düngung Bodenkd. 1954, 64, 1-8. [CrossRef]

71. Leonardi, M.; Caruso, G.M.; Carroccio, S.C.; Boninelli, S.; Curcuruto, G.; Zimbone, M.; Allegra, M.; Torrisi, B.; Ferlito, F.; Miritello, M. Smart nanocomposites of chitosan/alginate nanoparticles loaded with copper oxide as alternative nanofertilizers. Environ. Sci. Nano 2021, 8, 174-187. [CrossRef]

72. Klingebiel, A.A.; Montgomery, P.H. Land Capability Classification; Agriculture USDA: Washington, DC, USA, 1961.

73. Saitta, D.; Consoli, S.; Ferlito, F.; Torrisi, B.; Allegra, M.; Longo-Minnolo, G.; Ramírez-Cuesta, J.M.; Vanella, D. Adaptation of citrus orchards to deficit irrigation strategies. Agric. Water Manag. 2021, 247, 106734. [CrossRef]

74. Ciaccia, C.; La Torre, A.; Ferlito, F.; Testani, E.; Battaglia, V.; Salvati, L.; Roccuzzo, G. Agroecological Practices and Agrobiodiversity: A Case Study on Organic Orange in Southern Italy. Agronomy 2019, 9, 85. [CrossRef]

75. Schmid-Egger, C.; Scheuchl, E. Illustrierte Bestimmungstabellen der Wildbienen Deutschlands und Österreichs Unter Berücksichtigung der Arten der Schweiz. In Band III, Andrenidae; Eigenverlag: Velden, Austria, 1997; p. 180.

76. Scheuchl, E. Illustrierte Bestimmungstabellen der Wildbienen Deutschlands und Österreichs. In Band I: Anthophoridae. 2. Erweiterte Auflage; Eigenverlag: Berlin, Germany, 2006; 158p.

77. Scheuchl, E. Illustrierte Bestimmungstabellen der Wildbienen Deutschlands und Österreichs Für Osmia s.1. Unter Berücksichtigung der Arten der Schweiz, Norditaliens, Ungarns, Sloweniens und der Slowakei. In Band II, Schlïssel der Arten der Familien Megachilidae und Melittidae, 2nd ed.; Apollo Books: Tsim Sha Tsui, Japan, 2006; p. 192.

78. Mazzei, P.; Morel, D.; Panfili, R. Moths and Buttes of Europe and North Africa. 2021. Available online: http://www.leps.eu (accessed on 2 November 2021).

79. Fürsch, H. Übersicht über die Genera und Subgenera der Scymnini mit besonderer Berücksichtigung der Westpalaearktis (Insecta, Coleoptera, Coccinellidae). Entomol. Abh. (Dresd.) 1987, 51, 57-74.

80. El-Saeady, A.A.; Hafez, S.F.; Abied, M.K.; Bedewy, M.M.M. Taxonomy of the Tribe Scymnini (Coleoptera: Coccinellidae: Scymninae). Egypt. Bull. Ent. Soc. 2016, 93, 117-150.

81. Brooks, S.J. A taxonomic review of the common green lacewing genus Chrysoperla (Neuroptera: Chrysopidae). Bull. Br. Nat. Hist. (Entomol.) 1994, 63, 137-210.

82. Polaszek, A. Fauna Europaea: Apidae. In Fauna Europaea: Hymenoptera-Apocryta. Fauna Europaea Version 2.6; Mitroiu, M.D., Noyes, J., Cetkovic, A., Nonveiller, G., Radchenko, A., Polaszek, A., Ronquist, F., Forshage, M., Pagliano, G., Gusenleitner, J., et al., Eds.; Fauna Europaea Secretariat: Berlin, Germany, 2013. Available online: http:/ / www.fauna-eu.org (accessed on 27 July 2021).

83. Turrisi, G.F.; Bella, S.; Catania, R.; La Greca, P.; Nobile, V.; D’urso, V. Bee diversity in fragmented areas of Volcano Etna (Sicily, Italy) at different degrees of anthropic disturbance (Hymenoptera: Apoidea, Anthophila). J. Entomol. Acarol. Res. 2021, $53,10362$. [CrossRef]

84. Lodolini, E.M.; Paoletti, A.; Nolasco, A.; Ferlito, F.; Cutuli, M.; Torrisi, B.F.; Santilli, E.; Zaffina, F.; Desando, M.; Rosti, A.; et al. Biomass recovery from olive rejuvenation pruning in different varieties. In Proceedings of the 29th European Biomass Conference and Exhibition, Marseille, France, 26-29 April 2021; pp. 273-278. [CrossRef] 